\section{To: (Receiving Organization) \\ Distribution}

\section{Proj./Prog./Dept./Div.:}

RPP/Tank Farms/Tech Ops/Equip Eng

3. From: (Originating Organization)
Equipment Engineering 74700
6. Design Authority/Design Agent/Cog. Engr.:
R. D. Gustavson

\section{Originator Remarks:}

Documents results of HEPA Filter Vulnerability Assessment requested by DOE-ORP. Key Words: High Efficiency Particulate Air (HEPA), filters, vulnerability, degradation, Authorization Basis, Double-Contained Receiver Tank (DCRT), cross-site transfer system. 11. Receiver Remarks:
O No

\section{Related EDT No: \\ $\mathrm{N} / \mathrm{A}$ \\ 7. Purchase Order No.: \\ $\mathrm{N} / \mathrm{A}$ \\ 9. Equip./Component No.:}

Ventilation Systems

10. System/Bldg./Facility:

241-G/Tank Farms

12. Major Assm. Dwg. No.:

N/A

13. Permit/Permit Application No.:

$\mathrm{N} / \mathrm{A}$

14. Required Response Date:

$5 / 11 / 00$

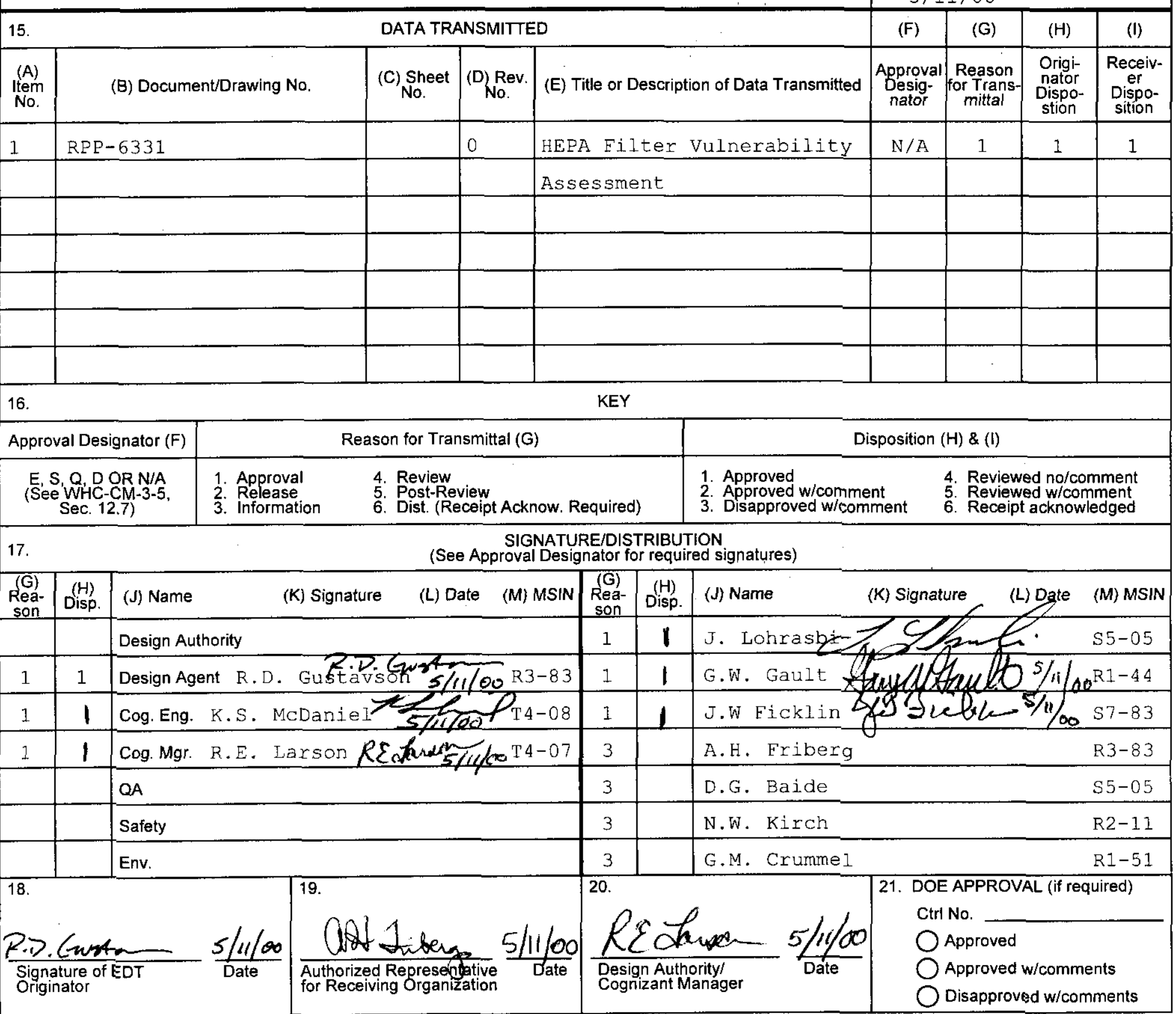




\title{
HEPA Filter Vulnerability Assessment
}

\author{
R. D. Gustavson \\ Prepared by CH2M Hill Hanford Group, Inc. \\ Richland, WA 99352 \\ U.S. Department of Energy Contract DE-AC06-99RL14047

$\begin{array}{ll}\text { EDT/ECN: } \quad 628099 & \text { UC: } \\ \text { Cost Center: } 74700 & \text { Charge Code: } 111282 \\ \text { B\&R Code: } & \text { Total Pages: } 4 D^{12}\end{array}$

Key Words: High Efficiency Particulate Air (HEPA), filters, vulnerability , degradation, Authorization Basis, Double-Contained Receiver Tank (DCRT), cross-site transfer system

Abstract: This document presents the results of a HEPA filter vulnerabilit $y$ assessment conducted for the River protection project as requested by the DOE Office of River Protection.

TRADEMARK DISCLAIMER. Reference herein to any specific commercial product, process, or service by trade name, trademark, manufacturer, or otherwise, does not necessarily constitute or imply its endorsement, recommendation, or favoring by the United States Government or any agency thereof or its contractors or subcontractors.

Printed in the United States of America. To obtain copies of this document, contact: Document Control Services, P.O. Box 950, Mailstop H6-08, Richland WA 99352, Phone (509) 372-2420; Fax (509) 376-4989.

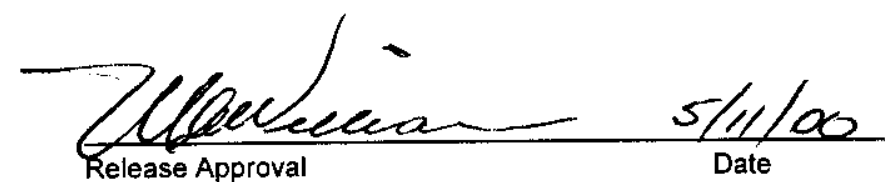

$\therefore$

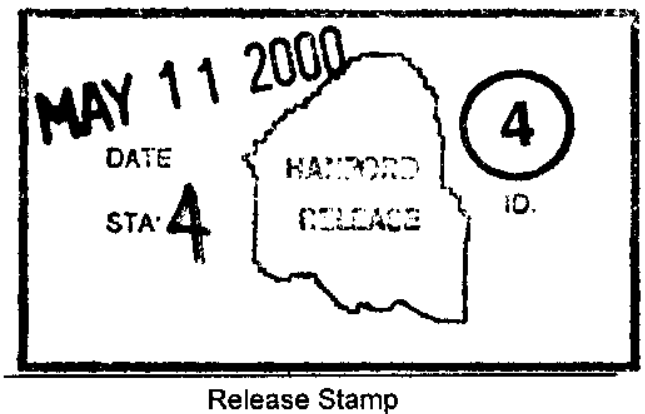

Release Stamp 
RPP-6331 Rev. 0

\section{HEPA Filter Vulnerability Assessment}

R. D. Gustavson

$\mathrm{CH} 2 \mathrm{M}$ Hill Hanford Group, Inc.

Date Published

May 2000

Prepared for the U.S. Department of Energy

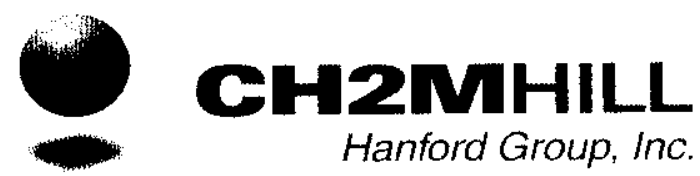

P.O. Box 1500

Richland, Washington

Hanford Management and Integration Contractor for the

U.S. Department of Energy under Contract DE-AC06-99RL14047 


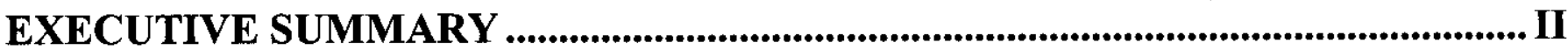

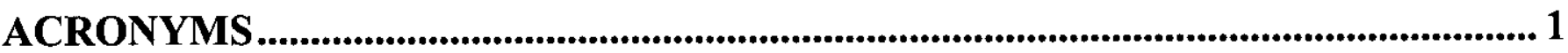

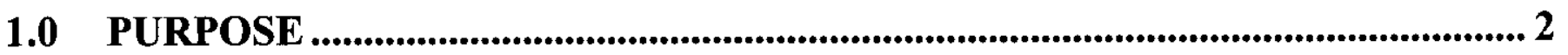

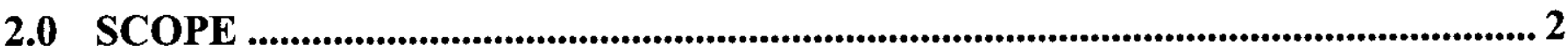

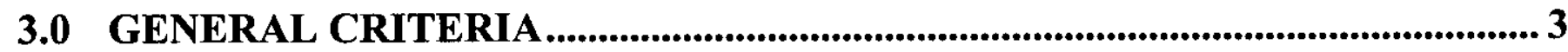

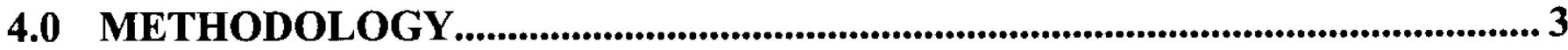

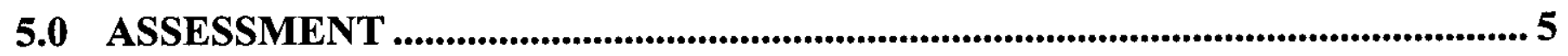

5.1 AUTHORIZATION BASIS REVIEW AND ASSESSMENT SCOPE ……....................................

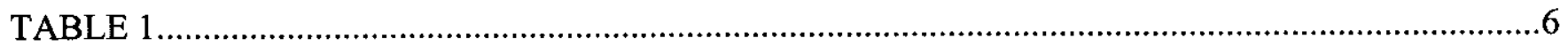

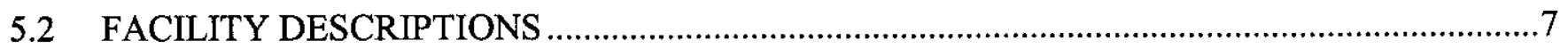

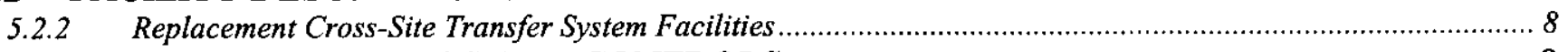

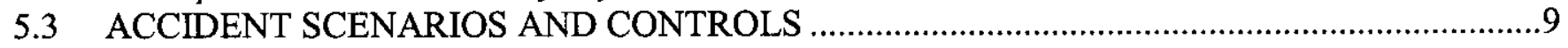

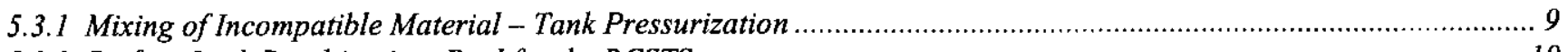

5.3.2 Surface Leak Resulting in a Pool for the RCSTS ..................................................................................... 10

5.3.3 Spray Leak in the RCSTS ........................................................................................................ 11

5.4 DEGRADATION FACTORS, THRESHOLD SCREENING, AND EVALUATION CRITERIA. 12

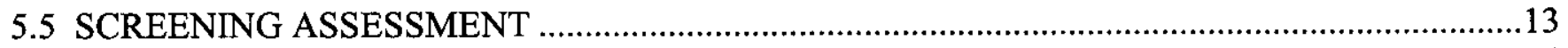

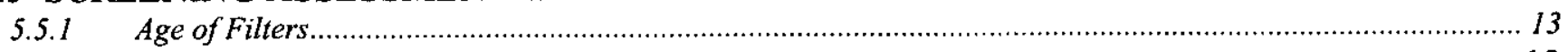

TABLE 2 …

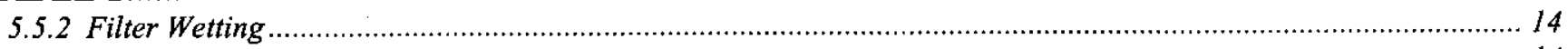

5.5 .3 High Temperature

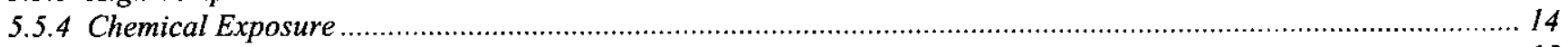

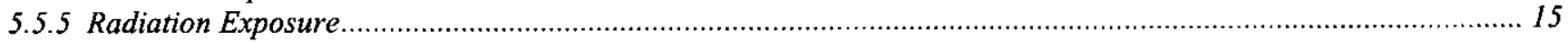

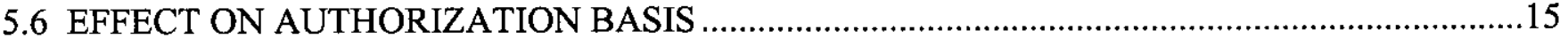

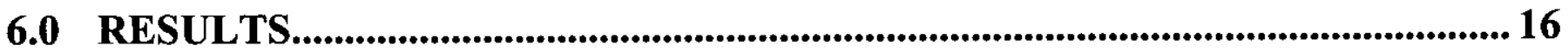

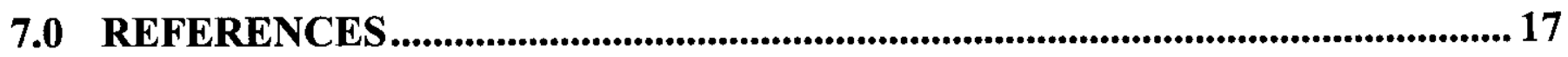




\section{Executive Summary}

This assessment of High Efficiency Particulate Air (HEPA) filter vulnerability was requested by the USDOE Office of River Protection (ORP) to satisfy a DOE-HQ directive to evaluate the effect of filter degradation on the facility authorization basis assumptions. Within the scope of this assessment are ventilation system HEPA filters that are classified as Safety-Class (SC) or Safety-Significant (SS) components that perform an accident mitigation function.

The objective of the assessment is to verify whether HEPA filters that perform a safety function during an accident are likely to perform as intended to limit release of hazardous or radioactive materials, considering factors that could degrade the filters. Filter degradation factors considered include aging, wetting of filters, exposure to high temperature, exposure to corrosive or reactive chemicals, and exposure to radiation.

Screening and evaluation criteria were developed by a site-wide group of HVAC engineers and HEPA filter experts from published empirical data. For River Protection Project (RPP) filters, the only degradation factor that exceeded the screening threshold was for filter aging. Subsequent evaluation of the effect of filter aging on the filter strength was conducted, and the results were compared with required performance to meet the conditions assumed in the RPP Authorization Basis (AB). It was found that the reduction in filter strength due to aging does not affect the filter performance requirements as specified in the $\mathrm{AB}$.

A portion of the HEPA filter vulnerability assessment is being conducted by the ORP and is not part of the scope of this study. The ORP is conducting an assessment of the existing policies and programs relating to maintenance, testing, and change-out of HEPA filters used for SC/SS service. 


\section{ACRONYMS}

\begin{tabular}{ll} 
AB & Authorization Basis \\
BIO & Basis of Interim Operation \\
CAM & Continuous Air Monitor \\
CHG & CH2M Hill Hanford Group, Inc. \\
CRAD & Criteria and Review Approach Document \\
dP & differential pressure \\
DCRT & Double-Contained Receiver Tank \\
DID & Defense-in-Depth \\
DNFSB & Defense Nuclear Facilities Safety Board \\
DOE & U.S. Department of Energy \\
DST & Double-Shell Tank \\
FSAR & Final Safety Analysis Report \\
GS & general service \\
h & hour \\
HEPA & High Efficiency Particulate Air \\
in. & inch or inches \\
JCS & Job Control System \\
lb & pound \\
LCO & Limiting Condition of Operation \\
NS\&L & Nuclear Safety \& Licensing \\
ORP & Office of River Protection \\
OSD & Operational Specification Document \\
PFP & Plutonium Finishing Plant \\
RCSTS & Replacement Cross-Site Transfer System \\
rem & Roentgen-equivalent man \\
RPP & River Protection Project \\
SC & safety class \\
SS & safety significant \\
SST & Single-Shell Tank \\
Sv & Seivert \\
TOD & Tank Farm Oversight Division \\
TSR & Technical Safety Requirement \\
WG & Water gauge \\
& \\
\hline
\end{tabular}




\subsection{PURPOSE}

This document presents the results of an assessment of potential vulnerability resulting from exposure of a select group of River Protection Project (RPP) High Efficiency Particulate Air (HEPA) filters to certain degradation factors. This HEPA filter vulnerability assessment was conducted in response to a Defense Nuclear Facilities Safety Board (DNFSB) Technical Report (DNFSB 1999). The DNFSB Report resulted in DOE headquarters direction to field offices (DOE-HQ 2000) to assess potential vulnerability from degraded HEPA filters. Subsequently, CH2M Hill Hanford Group, Inc., (CHG) was directed by the US Department Of Energy Office of River Protection (ORP) to conduct the assessment (DOE-ORP 2000).

The objective of the assessment, as stated in the Criteria and Review Approach Document (CRAD) guidance attachment to DOE-HQ 2000, is to verify whether HEPA filters that perform a safety function during an accident are likely to perform as intended to limit release of hazardous or radioactive materials, considering aging effects and the accident environment.

\subsection{SCOPE}

The DOE headquarters letter of direction (DOE-HQ 2000) limited the assessment to Hazard Category 1 and 2 nuclear facilities and any Category 3 facilities that, because of special circumstances such as material form, hazard type, or proximity to other facilities or the site boundary, depend on HEPA filters for protection of persons inside or outside the facility. Furthermore, the CRAD limits the scope for these facilities to those that rely on HEPA filters for accident mitigation. The CRAD also specifies that the assessments should:

1. Include all filters that perform an accident mitigation function (including standby or bypass filter banks), and not be limted to those filters "credited" in a safety analysis report (SAR).

2. Consider situations where degradation over time (e.g., aging, including the effects of environmental conditions during normal service life such as wetting, humidity, radiation or chemical exposure, or excessive pressure drop) may result in a filter's inability to perform its intended safety function during accident conditions that may stress the filter.

3. Consider accident environments and the ability of HEPA filters to perform their safety function in these environments (e.g., during explosions, fires, sprays, and high temperature exposure).

4. Provide information on how long the installed filters have been in service, and for information on existing policies and programs relating to maintenance, testing, and changeout. 
Additionally, the letter of direction from DOE-ORP to CHG (DOE-ORP 2000) limits the scope to those filters identified as safety class (SC) or safety significant (SS). The letter further states that ORP will conduct the portion of the assessment associated with item 4 above.

\subsection{GENERAL CRITERIA}

As suggested in the CRAD, the following general criteria were used for determining whether potential vulnerabilities exist and should be reported:

1. Safety Analysis Reports (SAR), Basis of Interim Operations (BIO) or other authorization basis or back-up documentation provides the following in accordance with DOE Orders:

- Analysis of accident conditions - 5480.23, paragraph 8.b.(k).

- Safety analyses including application of reliability engineering appropriate to control of vulnerabilities of the facility to accidents and accidental releases -5480.23 Attachment 1 , p.30, 11 a.

- Determination of whether the barriers to release will fail when challenged by the conditions resulting from the accident -5480.23 Attachment 1, p.32, c

2. The system design and technical information documentation meets criterion 1 requirements for accidents.

3. Filters are intact and there is no reason to believe that the assumptions of criterion 1 or 2 would be invalidated. Conditions within the ventilation system do not cause filter degradation beyond that assumed in the design and authorization basis.

4. A filter maintenance, testing, and change-out program is in place and current ${ }^{1}$.

The guidance of the CRAD states that not meeting any one of these criteria is a potential vulnerability and should be reported.

\subsection{METHODOLOGY}

Formal direction from ORP to proceed with the HEPA filter vulnerability assessment was received by CHG on April 3, 2000. The direction asked that the results of the assessment be reported to the ORP Tank Farm Oversight Division (TOD) no later than May 15, 2000. In recognition of the short schedule period for the assessment, it was established that reasonable effort in gathering and reviewing data was acceptable. Local document sources were to be used, and no archive searches were required because of the short time period allowed for the assessment. Expectations for evidence and depth or rigor included the following as acceptable source documents: historical documents, interviews, surveys, test reports, and inspections.

\footnotetext{
' DOE-ORP has conducted this portion of the HEPA filter vulnerability assessment (DOE-ORP 2000), therefore this item is not within the scope of this assessment.
} 
The approach to the assessment followed these general steps:

1. Establish working interface with HVAC engineers and HEPA filter experts from other Hanford Site contractors to ensure a correct and consistent site-wide approach is taken for the assessment.

2. Establish the $\mathrm{CHG}$ assessment team.

3. Determine RPP filters within the scope of the assessment.

4. Review the Authorization Basis (AB), safety basis, and back-up documentation to determine if criteria 1 and 2 are satisfactory (see Section 3.0. GENERAL CRITERIA) and to identify accident scenarios for which the filters serve a mitigating safety function.

5. Determine potential filter degradation factors (e.g., aging, radiation, chemical exposure, wetting) associated with environmental conditions during normal service life.

6. Establish thresholds for degradation factors and develop screening criteria.

7. Develop evaluation criteria (e.g., filter strength, efficiency, loading) to validate $A B$ assumptions.

8. Evaluate degrading environmental conditions to which filters within scope are subjected.

9. From evaluation criteria, determine degradation effect on filters.

10. Determine whether filter degradation affects the $A B$ and identify potential vulnerability.

11. Document assessment and results, and transmit to DOE-ORP. 


\subsection{ASSESSMENT}

This section discusses filters within the scope of the assessment; related accident scenarios for which the filters provide a mitigating safety function; identification of potential degradation factors; development of screening thresholds and evaluation criteria for degradation factors; and results of data reviews, assessment activities, and evaluations of vulnerabilities.

\subsection{AUTHORIZATION BASIS REVIEW AND ASSESSMENT SCOPE}

The CHG Safety Analysis group within the Nuclear Safety \& Licensing (NS\&L) organization conducted a review of the RPP AB to determine those RPP HEPA filters that are within the scope of the assessment as defined in Section 2.0. This review is presented in Appendix A. The assessment scope is limited to HEPA filters that are classified in the RPP AB as SC or SS and that serve a safety function to mitigate the offsite or onsite consequences of postulated accidents in the $\mathrm{AB}$.

The $\mathrm{AB}$ review presented in Appendix $\mathrm{A}$ also looked at whether the RPP $\mathrm{AB}$ satisfactorily addresses criteria 1 and 2 of Section 3.0, GENERAL CRITERIA, of this document for the systems within scope. It was determined in the review that the RPP AB is compliant with the requirements of DOE Orders 5480.22 and 5480.23 in identifying hazardous conditions, documenting the resulting safety analyses, identifying controls to prevent or mitigate the evaluated accidents, and providing functional requirements for equipment credited in preventing or mitigating consequences.

There are five (5) RPP ventilation systems that have HEPA filters within the scope of this assessment. These systems are associated with aging Double-Contained Receiver Tank (DCRT) facilities or the relatively new Replacement Cross-Site Transfer System (RCSTS) constructed under Line Item Project W-058. Table 1 lists the relevant facilities, filter configurations, and filter safety classifications.

Presently, there is an AB amendment CHG,2000a) being considered for approval by the ORP that will result in classification of additional RPP HEPA filters as SS or SC. This amendment is to implement a replacement Technical Safety Requirement (TSR) control for Continuous Air Monitor (CAM)/Fan interlocks to detect HEPA filter failure assumed to result from the conditions of two postulated accidents. The replacement control will take credit for HEPA filter differential pressure (dP)/Fan interlock and two-stage filter redundancy for preventing or mitigating an airborne release as a result of HEPA filter failure from moisture loading of generated aerosols, high temperatures, or overpressurization. In addition, the accident scenarios that drive the need for the controls are being reanalyzed, which subsequently may preclude the need for classifying the filters as SS or SC. Use of these additional HEPA filters as part of TSR control strategies is being received by the ORP and has not been authorized by the ORP for use. Therefore, these additional HEPA filter systems are not included in this assessment. 


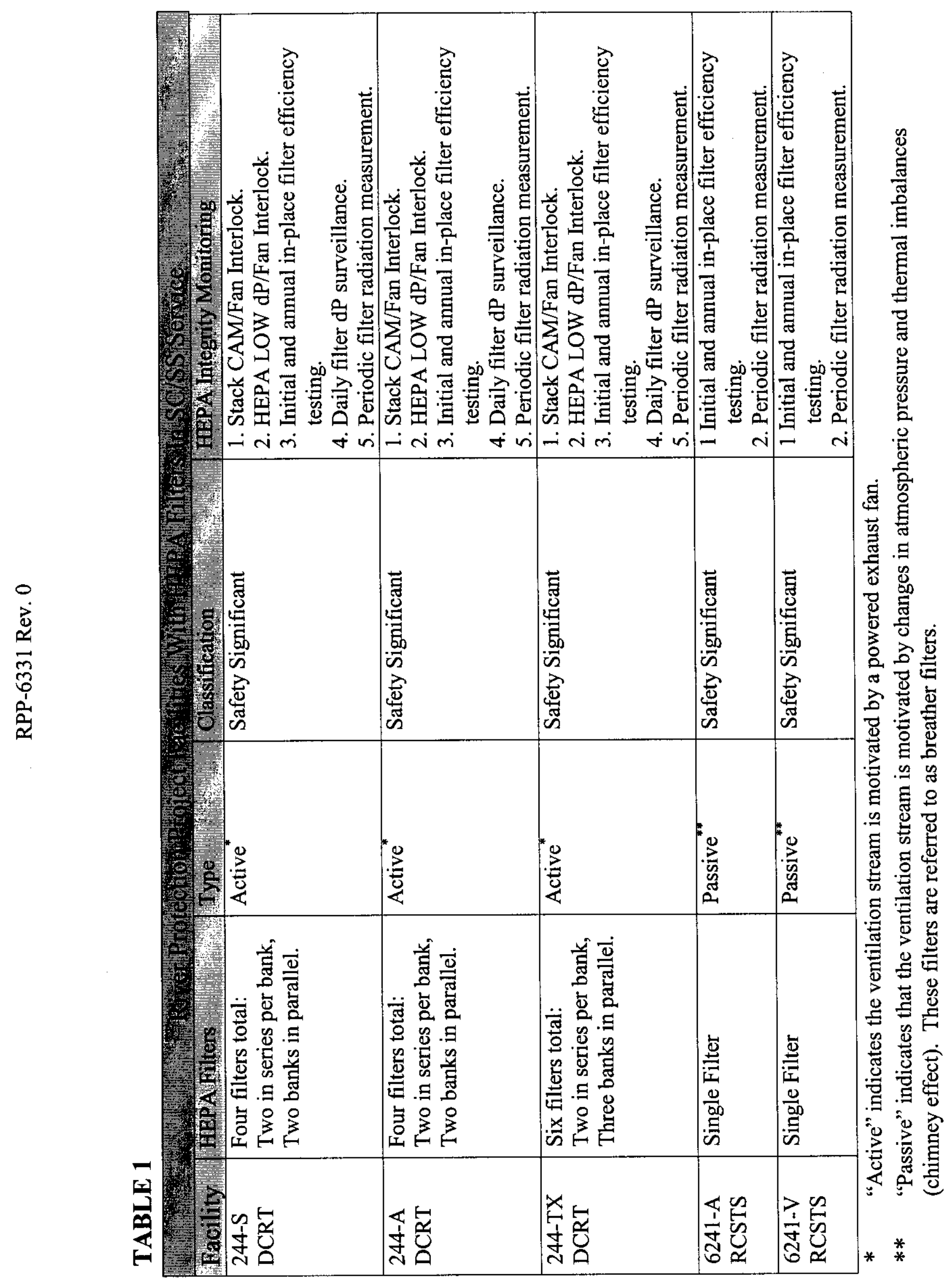




\subsection{FACILITY DESCRIPTIONS}

This section provides summary descriptions of the facilities that contain the filters within the scope of the vulnerability assessment. Included are:

- 244-S, 244-A, and 244-TX DCRT facilities and

- the RCSTS diversion box (6241-A) and vent station (6241-V).

For a more detailed description of these facilities, the reader is referred to HNF-SD-WM-SAR067, Tank Waste Remediation System Final Safety Analysis Report (CHG 2000d).

\subsubsection{Double-Contained Receiver Tank Facilities}

A DCRT is a short-term waste storage facility that consists of an underground filter pit, pump pit, and a containment vault in which a catch tank or receiver vessel is installed. The DCRT is used for interim storage of liquid waste and as a valve pit for waste transfer operations. At the Hanford Site, the terms "lift station" and "catch tank" have been used synonymously with DCRT. The DCRTs are used for receiving liquid waste transfers from other Hanford facilities, managing transfers of salt well waste (i.e., interstitial liquid) removed from the single-shell tanks (SST), and as a catch tank to receive waste transfer line drainage from both directions along the transfer line or contained leaks from ancillary equipment such as pumps, transfer lines, jumpers, valves, and flush lines.

The 244-TX DCRT receives waste from the Plutonium Finishing Plant (PFP) and liquid waste from the 241-T, 241-TY, and 241-TX SST Farms. The waste is transferred from the 244-TX DCRT to the 244-S DCRT before being routed to the 241-SY Double-Shell Tank (DST) Farm. The facility became operational in 1979 .

The 244-S DCRT receives waste from the 244-TX DCRT, the 222-S Laboratory, and the 241-S and 241-SX SST Farms. The waste is routed to the 241-SY DST Farm. Prior to the construction and operation of the RCSTS, cross-site waste transfers from the 241-SY DST Farm in 200 West Area to DST Farms in the 200 East Area were routed through the 244-S DCRT. The facility became operational in 1978.

The 244-A DCRT is located at the 244-A lift station, a low point in the old East-West cross-site transfer line and drain system. Prior to the construction and operation of the RCSTS, the 244-A DCRT provided lag storage for waste transfers from 200 West Area; from the 241-B, 241-BX, 241-BY, and 241-C SST Farms; and from B-Plant. The 244-A DCRT now serves primarily as a waste transfer system secondary containment catch tank. The facility became operational in 1975. 
The ventilation systems serve several purposes in the DCRT facilities. DCRT ventilation systems are designed to remove air, moisture, and heat from tank and annular spaces. The exhaust fans are designed to keep a negative air pressure inside the primary tank to prevent unfiltered air emissions from escaping from the DCRT/catch station. The air exhausted from the tanks and annuli passes through a heater, prefilter, and two stages of HEPA filters, and it is monitored for radiation before being released from the exhaust stack.

Each DCRT has its own unique ventilation system, but the principles used to process the air flow through equipment and filters are fairly consistent. Both the tank and annulus airspaces are routed to a common exhaust header and single exhaust fan.

Air enters the annulus via an intake system that includes a heater, prefilter and HEPA filter. The prefilter inhibits particulates from entering the vault. The HEPA filter prevents a contamination release if a backflow of annulus air occurs when the exhaust system is not operating. Outside air enters the tank only by seeping through covered risers. Because the resistance to airflow into the annulus is less than into the tank, the tank will have a greater negative pressure than the annulus.

Air from the tank and annulus is drawn through HEPA filter banks contained within the concrete filter pit. Each filter bank contains a prefilter and two HEPA filters in series. Each filter bank housing is removable by crane as a unit from the filter pit, which is enclosed with removable concrete cover blocks. A heater, located upstream of the filter banks, heats the air to reduce the relative humidity and thereby prevents condensation and wetting of the filters. DCRTS 244-S and 244-A have only two parallel filter banks, while the 244-TX DCRT has three.

Differential pressure (dP) indicators are installed across the intake and exhaust HEPA filter banks to monitor pressure drop. Detection of low dP across the final HEPA filter in each filter bank will automatically shut down the exhaust fan and sound an alarm.

Continuous emission samples are withdrawn from the exhaust stack and monitored for radioactivity using a continuous air monitor (CAM). Automatic shutdown of the ventilation system is actuated if increasing radiation is detected by the CAM above the setpoints.

\subsubsection{Replacement Cross-Site Transfer System Facilities}

The RCSTS is a buried pipe-in-pipe system approximately $10.5 \mathrm{~km}(6.5 \mathrm{mi})$ long. It provides a means of transferring SST waste, DST waste, and other liquid slurry wastes resulting from normal 200 West Area operations to the treatment, storage, and disposal facilities in the 200 East Area. The system was constructed under Project W-058 to replace the aging original cross-site transfer system, and it became operational in 1998.

The RCSTS provides buried transfer lines from the 241-SY DST Farm in the 200 West Area to a new diversion box (6241-A), also located in the 200 West Area. Two booster pumps are 
connected in parallel to one of the transfer lines in this diversion box. Air passes to and from the diversion box (because of temperature and pressure changes) through a HEPA "breather" filter connected to a $15 \mathrm{~cm}(6-\mathrm{in})$ pipe that penetrates the wall at grade level near the roof. A portable exhauster can be connected to the air exhauster hook-up line to provide powered ventilation, if necessary.

From diversion box $6241-\mathrm{A}$, the lines travel to vent station $6241-\mathrm{V}$ at the high point in the route located approximately midway between the 200 West and East Areas. Each transfer line has a vent at the high point that can be opened after waste transfer pumping is completed to allow air to be drawn into the line through a HEPA filter within the vent station, so that the line can drain by gravity to the sending and receiving tanks. Air passes to and from the vent station (as a result of temperature and pressure changes) through a HEPA "breather" filter connected to a $15 \mathrm{~cm}$ (6in) pipe that penetrates the wall at grade level near the roof. A portable exhauster can be connected to the air exhauster hook-up line to provide powered ventilation, if necessary.

The RCSTS transfer lines continue on to the 244-A lift station in the 200 East Area. The lines are connected to new transfer nozzles that are installed in the lift station wall.

\subsection{ACCIDENT SCENARIOS AND CONTROLS}

This section discusses the postulated accidents for which the HEPA filters that are in scope of the vulnerability assessment perform an accident mitigation function. Also discussed are additional safety controls and operational limits that either prevent an accident or ensure that the effects of a loss of HEPA filtration will be detected and mitigated.

For a more detailed description of the postulated accidents and safety controls, the reader is referred to HNF-SD-WM-SAR-067, Tank Waste Remediation System Final Safety Analysis Report (CHG 2000d) and HNF-SD-WM-TSR-006, Rev. 1, Tank Waste Remediation System Technical Safety Requirements (CHG 2000c).

\subsubsection{Mixing of Incompatible Material - Tank Pressurization}

A mistransfer of incompatible waste to a DCRT was identified in the hazard analysis performed for tank farms as an initiating event for a hazardous material release. Based on the hazard analysis and research conducted in the development of this accident scenario, it was determined that this scenario applies only to DCRTs 244-A, 244-S, and 244-TX.

The postulated accident scenario assumes the inadvertant addition of nitric acid to tank waste from an unneutralized transfer of PFP waste or when intending to add $\mathrm{NaOH}$ for $\mathrm{pH}$ adjustment. In the analysis, the mistransfer of nitric acid leads to a chemical reaction, tank pressurization, and 
subsequent release of aerosols to the environment. The peak pressure in the tank is to be $5 \mathrm{lb} / \mathrm{in}^{2}$ gauge, assuming flow only through the vent line from the tank to the filters.

The accident scenario with controls credits a Technical Safety Requirement (TSR) transfer control that requires a compatibility evaluation to ensure $\mathrm{pH}$ is greater than 8 before waste is transferred into a tank farm. This control effectively prevents the accident. For the bounding scenario analyzed, the HEPA filters would likely fail because of the overpressurization and therefore were not credited. In less severe scenarios, however, the HEPA filters might serve to mitigate the release. Accordingly, one stage of HEPA filters have been designated SS for the 244-A, 244-S, and 244-TX DCRTs².

HEPA filter related TSR controls for the DCRTs include:

- Periodic verification that both the HEPA filter housing radiation level and the prefilter before filter housing radiation levels are $2 \mathrm{mSv} / \mathrm{h}(200 \mathrm{mrem} / \mathrm{h})$ on contact. This control protects an analysis assumption for the amount of radioactive material postulated to be released when a HEPA filter fails.

- HEPA filter aerosol efficiency testing after installation and periodically thereafter to ensure filtering efficiency of HEPA filters.

Additional Defense-in-Depth controls include:

- Stack CAM/Fan Interlock

- HEPA LOW dP/Fan Interlock ( $2^{\text {nd }}$ HEPA stage, each bank)

- High filter dP Operating Specification Document (OSD) limits of $<5.9$ in. WG.

- Daily filter $\mathrm{dP}$ surveillance (when vent system is operating).

\subsubsection{Surface Leak Resulting in a Pool for the RCSTS}

A waste leak within the 6241-A diversion box or the 6241-V vent station could form a pool. Leaks were evaluated in the two RCSTS structures, with diversion box 6241-A providing the bounding case. The maximum leak rate is assumed to be $1.3 \mathrm{~L} / \mathrm{s}(20 \mathrm{gpm})$, and the leak detector

\footnotetext{
${ }^{2}$ HEPA filters are assumed to fail when pressures exceed a manufacturer's pressure rating of 10 in WG $\left(0.31 \mathrm{lb} / \mathrm{in}^{2}\right)$. The assumption that the filters serve to mitigate release in scenarios less severe than the bounding scenario has not been quantified. The elevation of HEPA filtration from Defense-In-Depth (DID) General Service (GS) classification to Safety-Significant (SS) for this accident has been recognized as not necessary, since the accident is effectively prevented with transfer controls. Hence, an $\mathrm{AB}$ amendment has been transmitted to DOE-ORP that downgrades the DCRT Filters from SS to DID/GS for this accident. (see Reference CHG 2000b)
} 
in the diversion box is assumed to alarm after $51 \mathrm{~mm}(2 \mathrm{in}$.) of waste has accumulated. Flow is also assumed to occur for 30 minutes after the leak detector alarms to allow for operator response time to shut down the transfer pump. A TSR control was selected to ensure that the doors and pipe penetrations in diversion box $6241-\mathrm{A}$ and vent station $6241-\mathrm{V}$ are sealed during waste transfers to limit the release of unfiltered aerosols. This is assumed in the analysis, and therefore the majority $(90 \%)$ of the airborne release will pass through a passive HEPA filter, which is credited with reducing the source term released to the atmosphere.

A TSR filter efficiency control was selected for the breather HEPA filter in diversion box 6241A and vent station $6241-\mathrm{V}$ to limit doses to the onsite receptor and facility worker. The filters are given a safety designation of SS.

A HEPA filter control program is in place with the following key elements:

- Periodic radiation surveys to monitor HEPA filter loading.

- HEPA filter replacements per change-out criteria; i.e., $2 \mathrm{mSv} / \mathrm{h}(200 \mathrm{mrem} / \mathrm{h})$.

- In place aerosol testing of installation.

- Periodic in-place aerosol test, .

HEPA filter monitoring and replacement reduce consequences from a possible HEPA filter failure by limiting the inventory available for release. Aerosol testing ensures filtering efficiency of the HEPA filter.

\subsubsection{Spray Leak in the RCSTS}

A breach of containment during a transfer through the RCSTS could result in a pressurized spray release. These spray releases are a safety concern because, depending on the waste pressure and leak dimensions, they can be relatively efficient generators of respirable-sized aerosols. For the RCSTS, spray leaks were evaluated in the two RCSTS structures, with diversion box 6241-A providing the bounding case.

A TSR filter efficiency control was selected to ensure that the doors and pipe penetrations in diversion box $6241-\mathrm{A}$ and vent station $6241-\mathrm{V}$ are sealed during waste transfers to limit the release of unfiltered aerosols. This is assumed in the analysis, and therefore the majority (90\%) of the airborne release will pass through a passive HEPA filter, which is credited with reducing the source term released to the atmosphere.

A TSR control was selected for the breather HEPA filter in diversion box 6241-A and vent station $6241-\mathrm{V}$ to limit doses to the onsite receptor and facility worker. The filters are given a safety designation of SS. 
A HEPA filter control program is in place with the following key elements:

- Periodic radiation surveys to monitor HEPA filter loading.

- HEPA filter replacements per change-out criteria, i.e., $2 \mathrm{mSv} / \mathrm{h}(200 \mathrm{mrem} / \mathrm{h})$ on contact.

- In-place aerosol testing installation.

- Periodic in-place aerosol testing.

HEPA filter monitoring and replacement reduce consequences from a possible HEPA filter failure by limiting the inventory available for release. Aerosol testing ensures filtering efficiency of the HEPA filter.

\subsection{DEGRADATION FACTORS, THRESHOLD SCREENING, AND EVALUATION CRITERIA}

A Hanford Site HEPA Filter Vulnerability Assessment Team was formed for this effort that included Hanford Site HVAC and HEPA filter experts. This team chose potential filter degradation factors to be considered during this assessment. These degradation factors are consistent with functional requirements identified in the RPP Final Safety Analysis Report (FSAR) section 4.4.5.3 (CHG,2000d) include:

- Filter aging,

- Filter wetting,

- Exposure to high temperature,

- Exposure to chemicals, and

- Exposure to radiation.

Threshold values and screening criteria were then developed for use in a graded fashion to identify degradation factors requiring further evaluation for potential impact to required system performance. These were developed from HEPA filter degradation information in the literature citations recommended in the CRAD for use in the assessment (refer to DOE-HQ 2000). These screening criteria with threshold values are presented in Appendix B as Section A of the HEPA Filter Vulnerability Criteria.

Also developed were evaluation criteria to determine remaining filter strength, should there be a "yes" answer to any of the screening criteria. These evaluation criteria are presented in Appendix B as Section B of the HEPA Filter Vulnerability Criteria. 


\subsection{SCREENING ASSESSMENT}

The filters in scope were assessed as to the level that degradation factors may have impacted their required purpose through the application of the screening criteria. The assessment process calls for use of the evaluation criteria to evaluate the potential impacts to the required system performance in the event that any of the screening criteria apply. This section discusses the results of the application of the screening criteria for each of the degradation factors.

\subsubsection{Age of Filters}

A search of Job Control System (JCS) records was conducted for the subject HEPA filters to determine filter replacement dates, and hence approximate filter age. The JCS dates to approximately 1989. Because of the schedule for this vulnerability assessment was compressed, searches of archived material prior to that date were not conducted. Therefore, if a filter was not installed as part of a recent project or replaced within the time frame of the JCS system, filter age is assumed to be the date of initial installation (facility construction date). Table 2 below represents the results of the review.

\section{TABLE 2}

\begin{tabular}{|c|c|c|c|c|}
\hline$y=3$ & 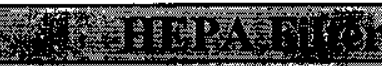 & & 99 & \\
\hline Fradition & Tilter Equipment & Work Package\# & Date & Filter A \\
\hline 244-A DCRT & $\mathrm{K} 1-3-2$ & 2E-97-01451 & $1 / 30 / 98$ & $<5$ years \\
\hline 244-A DCRT & K1-3-3 & $2 \mathrm{E}-97-01451$ & $1 / 30 / 98$ & $<5$ years \\
\hline 244-A DCRT & $\mathrm{K} 1-3-4$ & 2E-97-01451 & $1 / 30 / 98$ & $<5$ years \\
\hline 244-A DCRT & K1-3-5 & $2 \mathrm{E}-97-01451$ & $1 / 30 / 98$ & $<5$ years \\
\hline 244-S DCRT & S-22-BK-K1-3-2 & $2 \mathrm{~W}-95-00133$ & $1 / 10 / 96$ & $<5$ years \\
\hline 244-S DCRT & S-22-BK-K1-3-3 & $2 \mathrm{~W}-95-00133$ & $1 / 10 / 96$ & $<5$ years \\
\hline 244-S DCRT & S-22-BK-K1-3-4 & None & N/A & $<25$ years $^{\mathrm{a}}$ \\
\hline 244-S DCRT & S-22-BK-K1-3-5 & None & N/A & $<25$ years $^{\mathrm{a}}$ \\
\hline 244-TX DCRT & T-18-BK-1-FLTR-6 & None & N/A & $<25$ years $^{\mathrm{b}}$ \\
\hline 244-TX DCRT & T-18-BK-1-FLTR-7 & None & N/A & $<25$ years $^{b}$ \\
\hline 244-TX DCRT & T-18-BK-1-FLTR-8 & $2 \mathrm{~W}-90-02559$ & $1 / 27 / 93$ & $<10$ years \\
\hline 244-TX DCRT & T-18-BK-1-FLTR-9 & $2 \mathrm{~W}-90-02559$ & $1 / 27 / 93$ & $<10$ years \\
\hline 244-TX DCRT & T-18-BK-1-FLTR-10 & None & N/A & $<25$ years ${ }^{b}$ \\
\hline 244-TX DCRT & T-18-BK-1-FLTR-11 & None & N/A & $<25$ years $^{\mathrm{b}}$ \\
\hline $6241-\mathrm{A}$ & HEPA-A & None & N/A & $<5$ years $^{\mathrm{c}}$ \\
\hline $6241-\mathrm{V}$ & HEPA-V & None & $\mathrm{N} / \mathrm{A}$ & $<5$ years $^{\mathrm{c}}$ \\
\hline
\end{tabular}

\footnotetext{
${ }^{\text {a }}$ No JCS record of filter replacement. Assume original filter installed during 244-S construction in 1978.

${ }^{\mathrm{b}}$ No JCS record of filter replacement. Assume original filter installed during 244-TX construction in 1979.

c No JCS record of filter replacement. These are original filters installed during RCSTS construction in 1998.
} 


\subsubsection{Filter Wetting}

In accordance with the vulnerability assessment screening criteria, filter wetting is not an applicable degradation factor for the filters in question. It is believed that filter wetting of any significance has not occurred for the filters assessed.

Neither the 6241-A diversion box nor the 6241-V vent station have mechanisms under normal operations that would expose the breather filters to aerosols, entrained moisture, or heavy condensation. The DCRTs have installed heaters that heat the air stream both at the ventilation system inlet and just upstream of the HEPA filters to maintain relative humidity to acceptable levels and prevent condensation on the filters. There are no fire deluge systems for any of the assessed systems. The filters are rated by the manufacturer as moisture resistant.

\subsubsection{High Temperature}

The filters assessed are not installed in high temperature applications, and the filters have not been exposed to high temperatures as defined in the vulnerability assessment screening criteria $\left(>120^{\circ} \mathrm{C}\right)$.

The breather filters at the 6241-A diversion box and the 6241-V vent station are subject to ambient environmental temperatures.

For the DCRTs 244-S and 244-TX, Operating Specification Documents (OSDs) limit tank content temperatures to a maximum of $200^{\circ} \mathrm{F}\left(93.3^{\circ} \mathrm{C}\right)$. The ventilation systems are only required to be operating when tank waste surface temperatures are greater than or equal to $140^{\circ} \mathrm{F}$ $\left(60^{\circ} \mathrm{C}\right)$ or when transferring waste into the tank with a temperature greater than or equal to 140 ${ }^{\circ} \mathrm{F}\left(60^{\circ} \mathrm{C}\right)$. At $244-\mathrm{S}$ DCRT, the ventilation heater shuts off when the air stream temperature reaches $210^{\circ} \mathrm{F}\left(99^{\circ} \mathrm{C}\right)$. At 244-TX DCRT, the ventilation heater is a low temperature air dryer that is always on when the fan is on and typically provides an approximate $5^{\circ} \mathrm{F}$ temperature rise.

For 244-A DCRT, average air stream temperature at the outlet of the heater just upstream of the HEPA filters is $90^{\circ} \mathrm{F}\left(32.2^{\circ} \mathrm{C}\right)$. The ventilation heater shuts off when the air stream temperature reaches $210^{\circ} \mathrm{F}\left(99^{\circ} \mathrm{C}\right)$.

The filters are rated by the manufacturer as Fire Resistant.

\subsubsection{Chemical Exposure}

Degradation of the assessed HEPA filters (media, adhesives, frames, etc.) from contact with condensing chemical constituents in the air stream is unlikely. The breather filters in the 6241-A diversion box and the $6241-\mathrm{V}$ vent station are not exposed to degrading chemicals during normal 


\section{RPP-6331 Rev.0}

operation. Tank exhaust air streams for the DCRTs are estimated to contain very low concentrations of ammonia and Volatile Organic Carbon (VOC) compounds as the major chemical constituents, and the air stream is heated upstream of the HEPA filters during ventilation system operation to prevent condensation on the filters. The DCRT filters are manufactured and rated to be Fire Resistant, Moisture Resistant, and Chemical Resistant. Additionally, since DCRT ventilation systems are only operated intermittently, the filters are not exposed to these concentrations for significant periods of time.

A best estimate of chemical source term to which the DCRT filters may have been exposed is provided in Appendix C. Experimental data regarding degradation of filters from chemicals at various concentrations have not been developed to the degree necessary to qualitatively determine degradation effects.

\subsubsection{Radiation Exposure}

Filter degradation as a result of prolonged radiation exposure is not a concern for the RPP HEPA filters within the scope of this vulnerability assessment.

RPP TSR controls require that the HEPA filters be replaced before reaching a $200 \mathrm{mrem} / \mathrm{h}$ contact reading on the filter housing. The threshold value in the screening criteria for filter degradation from radiation exposure is an accumulated total dose of $>5 \times 10^{7} \mathrm{Rad}$, which corresponds to a constant dose rate of approximately $144 \mathrm{rad} / \mathrm{h}$ for 50 years. This equates to approximately $114,000 \mathrm{mrem} / \mathrm{h}$, which is approximately 570 times the limit allowed at RPP.

\subsection{EFFECT ON AUTHORIZATION BASIS}

The result of application of the degradation screening criteria is that only aging has a degradation effect on the HEPA filters within scope of this vulnerability assessment. Per the evaluation criteria of Appendix B, the effect on filter burst strength from the aging degradation factor is to reduce it from $4.6 \mathrm{lb} / \mathrm{in}^{2}$ to some lower value based upon age.

As presented in Table 2 of section 5.5.1, there are a total of six (6) filters that are assumed to be between 20 and 25 years old. Two (2) of the filters in scope are between 5 and 10 years old, and eight (8) of the filters are less than 5 years old.

From Table 1 of the evaluation criteria of Appendix B, conservative estimates of remaining filter strength are as follows:

- $4.1 \mathrm{lb} / \mathrm{in}^{2}$ for the two RCSTS breather filters in 6241-A and 6241-V ( $<5$ years old).

- $4.1 \mathrm{lb} / \mathrm{in}^{2}$ for all four filters in $244-\mathrm{A}$ DCRT $(<5$ years old). 
- $4.1 \mathrm{lb} / \mathrm{in}^{2}$ for two of the four filters in $244-\mathrm{S}$ DCRT ( $<5$ years old).

- $3.5 \mathrm{lb} / \mathrm{in}^{2}$ for two of the six filters in 244-TX DCRT ( $>5$ years old, but $<10$ years old).

- $1.9 \mathrm{lb} / \mathrm{in}^{2}$ for two of the four filters in 244-S DCRT ( $>20$ years old, but $<25$ years old).

- $1.9 \mathrm{lb} / \mathrm{in}^{2}$ for four of the six filters in 244-TX DCRT ( $>20$ years old, but $<25$ years old).

For the accident scenario associated with the RCSTS breather filters, the spray leak scenarios are not postulated to create the levels of pressure within the 6241-A diversion box and 6241-V vent station structures that would be necessary to cause the filters to fail. Therefore, filter strength is not degraded to a point where the assumptions of the RPP AB would be affected.

For the DCRTs, the filters are conservatively assumed in the RPP AB to fail at the manufacturer's pressure rating of $10 \mathrm{in}$. WG $\left(0.31 \mathrm{lb} / \mathrm{in}^{2}\right)$, so reduction of filter strength from aging does not impact the performance requirements as specified in the RPP AB.

Even if the filters within the scope of this assessment were as old as 30 years; were assumed to have been wetted multiple times; and were exposed to high temperature greater than $250^{\circ} \mathrm{C}$, they would still maintain a filter strength ${ }^{3}$ greater than the assumed failure pressure (for the DCRT filters) or the pressures they would be subjected to (for the RCSTS breather filters) for the Accident scenarios of the RPP AB.

\subsection{RESULTS}

This HEPA filter vulnerability assessment identified no potential vulnerabilities for the filters within the scope of the assessment. The ORP portion of the assessment may identify findings with the existing policies and programs relating to maintenance, testing, and change-out. This portion of the DOE-HQ requested vulnerability assessment is not part of this contractor effort.

\footnotetext{
${ }^{3}$ Per the evaluation criteria of Appendix $B$.
} 


\subsection{REFERENCES}

CHG 2000a

CHG 2000b

CHG 2000c

CHG 2000d

DOE-HQ 2000

DOE-ORP 2000

DNFSB 1999
Letter, $C H G-0000622$ R1, W. T. Dehn, CHG, to R. T. French, Orp, Contract Number DE-AC06-9914047; Performance Incentive ORP 3.2.3, "Implementation of Field Optimizations," Section 3, Standard 2, and Section 4, Item 2(6), dated April 13, 2000

Letter, CHG-0002045.1, W. T. Dehn, CHG, to R. T. French, ORP, Contract Number DE-AC06-9914047; Proposed Authorization basis Amendment For Modifying Double Contained Receiver Tank High Efficiency Particulate Air Filter Efficiency Administrative Control 5.18.2E To Defense-In-Depth, dated May 8, 2000.

HNF-SD-WM-TSR-006, Rev. 1, Tank Waste Remediation System Technical Safety Requirements, CH2M Hill Hanford Group, Inc, Richland Washington.

HNF-SD-WM-SAR-067, Rev. 1, Tank Waste Remediation System Final Safety Analysis Report, CH2M Hill Hanford Group, Inc, Richland Washington.

Letter, T. J. Glauthier, Deputy Secretary of Energy, distributed to DOE Field Offices including R. T. French, Manager, Office of River Protection, Action: Assess Potential Vulnerability Due to Degraded High-Efficiency Particulate Air (HEPA) Filters in Nuclear Facilities, dated March 1, 2000.

Letter, J. J. Short, II, ORP, to M. P. DeLozier, CHG, Contract No. DEAC06-99RL14047 - Assess Potential Vulnerability Due to Degraded High-Efficiency Particulate Air (HEPA) Filters in Nuclear Facilities, 0001591/00-TOD-015, dated March 31, 2000.

Defense Nuclear Facilities Safety Board Technical Report \#23, HEPA Filters Used in the Department of Energy's Hazardous Facilities, May 1999. 
RPP-6331 Rev.0

Appendix A

Interoffice Memo 74F00-GWG-2000-031

NS\&L Review of RPP AB for HEPA

Vulnerability Assessment

Consisting of 10 pages including this cover page 
From: $\quad$ Safety Analysis/Nuclear Safety \& Licensing

74F00-GWG-2000-031

Phone: 373-3132

Date: $\quad$ April 27, 2000

Subject: $\quad$ NS\&L INPUT FOR HEPA FILTER VULNERABILITY ASSESSMENT

To:

R. D. Gustavson

Copies:

G. W. Gault

NS\&L LB/file

This memorandum is in response to the following action assigned to Nuclear Safety and Licensing as part of the team responding to the High Efficiency Particulate Air (HEPA) Filter Vulnerability Assessment:

"For the filter systems in scope, review the Authorization Basis, safety basis, and back-up documentation to determine if it meets criteria 3.0 (a) and (b) of the Criteria and Review Approach Document (CRAD) attached to the letter of direction from DOE/ORP (letter 00-TOD-015). Provide the results of review as an internal memo."

The results of the review show that the HEPA filters associated with the following facilities meet the referenced criteria. Details of the review are presented in the Attachment to this memorandum.

- 244-S Double Contained Receiver Tank (DCRT)

- 244-A DCRT

- 244-TX DCRT

- 6241-A Replacement Cross Site Transfer System (RCSTS) Diversion Box

- 6241-V RCSTS Vent Station

If you have any questions, please contact me on 373-3132 or Gary Gault on 376-9707.

Signature copy on file.

R. J. Cash

gwg/drh

Attachment 
RPP-6331 Rev.0

74F00-GWG-2000-031

Attachment

REVIEW OF THE TANK FARM AUTHORIZATION BASIS

IN RESPONSE TO THE

HEPA FILTER VULNERABILITY ASSESSMENT

Consisting of 7 pages, including cover page 


\section{Background}

The following action was assigned to Nuclear Safety and Licensing as part of the team responding to the HEPA Filter Vulnerability Assessment:

"For the filter systems in scope, review the Authorization Basis, safety basis, and back-up documentation to determine if it meets criteria 3.0 (a) and (b) of the Criteria and Review Approach Document (CRAD) attached to the letter of direction from DOE/ORP (letter 00-TOD-015). Provide the results of review as an internal memo."

The HEPA filter vulnerability assessment is being conducted in response to a Defense Nuclear Facilities Safety Board (DNFSB) Technical Report (DNFSB Report 23 - HEPA Filters Used in the Department of Energy's Hazardous Facilities). The DNFSB Report resulted in DOE headquarters direction to field offices to "Assess Potential Vulnerability Due to Degraded HighEfficiency Particulate (HEPA) Filters in Nuclear Facilities" (Reference 1). Reference 2 provided specific direction to CH2M HILL Hanford Group, Inc. (CHG) to conduct this assessment.

DNFSB guidance attached to Reference 1 provides scope definitions and criteria to identify the HEPA filters of concern within the initial population. The specific criteria referenced in the Action defined above are as follows:

3.0 (a) SARs, Basis of Interim Operations (BIOs), or other safety basis or backup documentation provide the following in accordance with Department of Energy (DOE) Orders:

- Analysis of accident conditions - DOE Order 5480.23, paragraph 8.b.(k).

- Safety analyses including application of reliability engineering appropriate to control of vulnerabilities of the facility to accidents and accidental releases DOE Order 5480.23, Attachment 1, p.30, 11 a.

- Determination of whether or not the barriers to release will fail when challenged by the conditions resulting from the accident - DOE Order 5480.23, Attachment 1, p.32, e.

3.0 (b) The system design and technical information documentation meets criterion (a) requirements for accidents.

The letter of direction from the U.S. Department of Energy, Office of River Protection (ORP) (Reference 2) provided additional guidance to define the HEPA filter systems to be included within the scope of the vulnerability assessment as follows: "The scope of the vulnerability assessment should be limited to safety class or safety significant filters that perform an accident mitigation function."

\section{Evaluation}

Based on the above criteria and guidance, NS\&L reviewed all River Protection Project (RPP) Authorization Basis (AB) documents to identify the HEPA filter systems to be included in the scope of the vulnerability assessment. The RPP Final Safety Analysis Report (FSAR) and related Technical Safety Requirements (TSRs) are compliant with the requirements of DOE Orders 
5480.23 and 5480.22 , respectively. The FSAR identifies hazardous conditions, documents the resulting safety analyses, identifies controls to prevent or mitigate the evaluated accidents, and provides functional requirements for equipment credited in preventing or mitigating consequences.

Separate AB documents also exist for a limited number of RPP facilities that are not yet included within the scope of the RPP FSAR. These documents are not Order compliant but have been determined to be acceptable until actions are completed to decommission the facilities or to upgrade analyses for inclusion in the FSAR.

Relevant details of accident analyses included in the RPP AB documents are presented in Table 1. This table includes a determination of whether the subject application of HEPA filters meets the criteria for being included in the vulnerability assessment.

Due to lack of detailed information in the $A B$ documents for the three RPP facilities (209-E, 242-S, and 242-T) that do not have DOE Order compliant Safety Analysis Reports, additional evaluations to determine if the HEPA filters meet the criteria were required:

209-E: The AB document referenced in Table 1 for this facility does include identification of safety Systems, Structures, and Components (SSCs). Section 4.a of the document identifies the exhaust ventilation system as a safety SSC. A review of the related analysis shows that the basis for this designation is the potential for generation of flammable gas in the facility. The ventilation system is credited in preventing the buildup of flammable gas in the facility. Since the HEPA filters provide no mitigative function related to the flammable gas hazard, the HEPA filters are not considered to be included as part of the safety SSCs. Therefore, the HEPA filters were not identified as a safety SSC and the HEPA filter systems do not meet the criteria for inclusion in the HEPA filter vulnerability assessment.

242-S: The $\mathrm{AB}$ document referenced in Table 1 for this facility does not include identification of safety SSCs. The AB document is a facility shutdown/standby plan and does not include detailed hazards or accident analysis. The document imposes prudent controls to address potential hazards until detailed analysis is completed. As identified in Table 1 , these controls include a requirement to keep the HEPA filter system in service.

The $\mathrm{AB}$ document states that as part of placing the facility in shutdown/standby, radioactive liquids were removed from the facility, systems were flushed to reduce amounts of residual materials, pipe lines were blanked, and the majority of the equipment was removed from service. Based on these actions to limit the amount of hazardous material remaining in the facility and the lack of activities and operations within the facility, the potential of an accident occurring having significant onsite or offsite consequences is very low. Therefore, it is concluded that identification of HEPA filter systems as safety SSCs is not appropriate for this facility and the HEPA filter systems do not meet the criteria for inclusion in the HEPA filter vulnerability assessment. 
242-T: The $A B$ document for this facility does not include identification of safety SSCs. The document does include a general analysis for a maximum credible accident (building collapse due to earthquake) in the shutdown/standby mode. The document imposes prudent controls to address potential hazards until detailed analysis is completed. As identified in Table 1, controls are imposed to maintain continuous HEPA filtration for all potentially contaminated facility exhaust airflows. The conclusion stated in the document is that the facility is a low hazard facility.

Detailed hazards and accident analyses are currently being developed for 242-T. Preliminary analysis from this effort support the conclusion reached in the $A B$ document that the potential of an accident occurring having significant onsite or offsite consequences as a result of an accident is very low. Therefore, it is concluded that identification of HEPA filter systems as safety SSCs is not appropriate for this facility and the HEPA filter systems do not meet the criteria for inclusion in the HEPA filter vulnerability assessment.

\section{Conclusions}

Based on the evaluation included in Table 1 and the additional evaluation above, HEPA filters for the following ventilation systems meet the scope criteria for inclusion in the HEPA filter vulnerability assessment:

- 244-S Double Contained Receiver Tank (DCRT) (minimum of one stage)

- 244-A DCRT (minimum of one stage)

- 244-TX DCRT (minimum of one stage)

- 6241-A Replacement Cross Site Transfer System (RCSTS) Diversion Box (minimum of one stage)

- 6241-V RCSTS Vent Station (minimum of one stage)

\section{References:}

1. Letter, T. J. Glauthier, Secretary of Energy, distributed to DOE Field Offices including R. T. French, Manager, Office of River Protection, "Action: Assess Potential Vulnerability Due to Degraded High-Efficiency Particulate Air (HEPA) Filters in Nuclear Facilities," dated March 1, 2000.

2. Letter, J. J. Short, II, ORP, to M. P. DeLozier, CHG, "Contract No. DE-AC06-99RL14047 Assess Potential Vulnerability Due to Degraded High-Efficiency Particulate Air (HEPA) Filters in Nuclear Facilities," 0001591/00-TOD-015, dated March 31, 2000. 


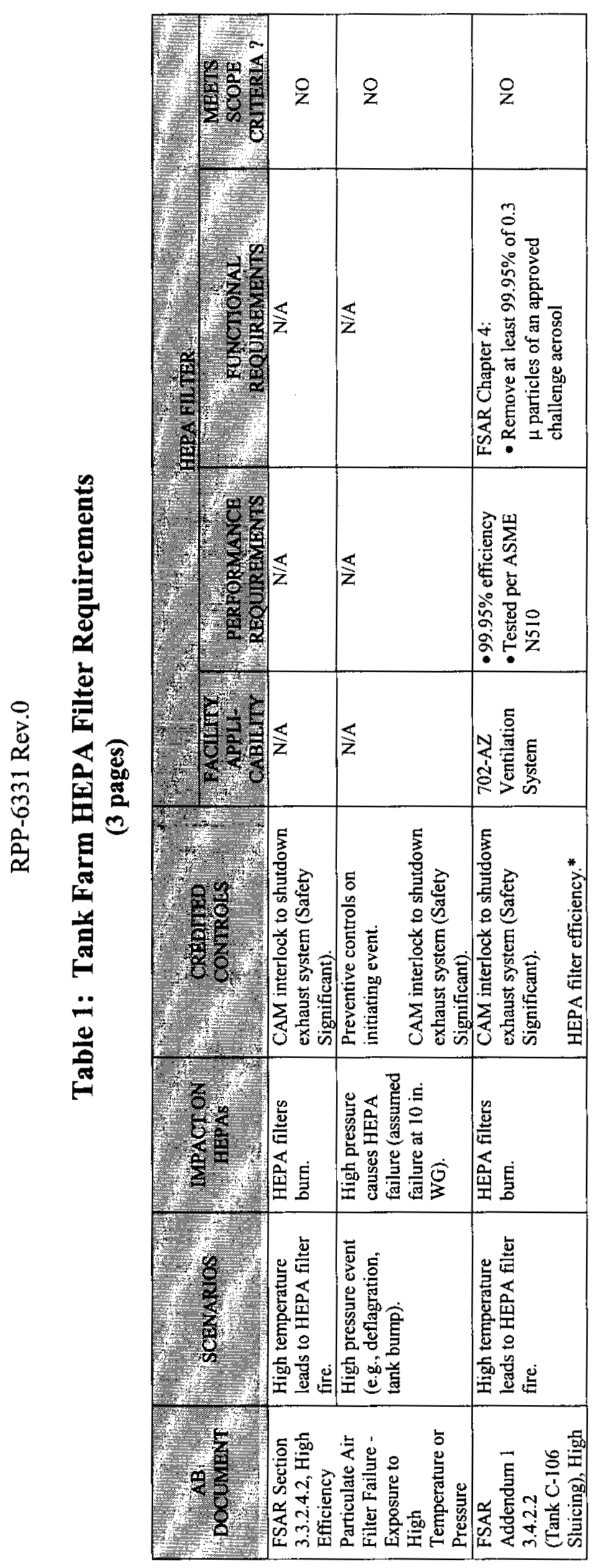




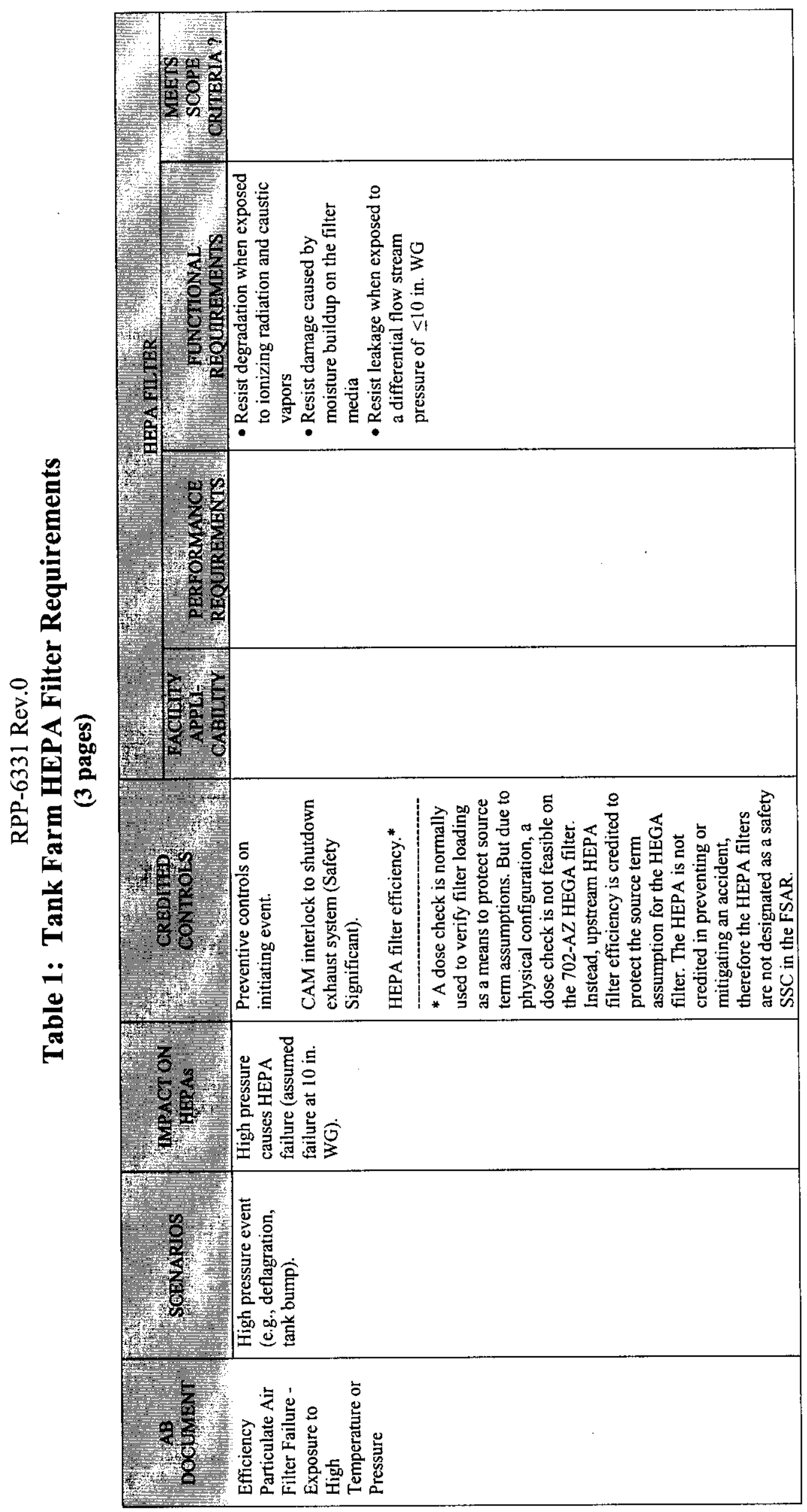




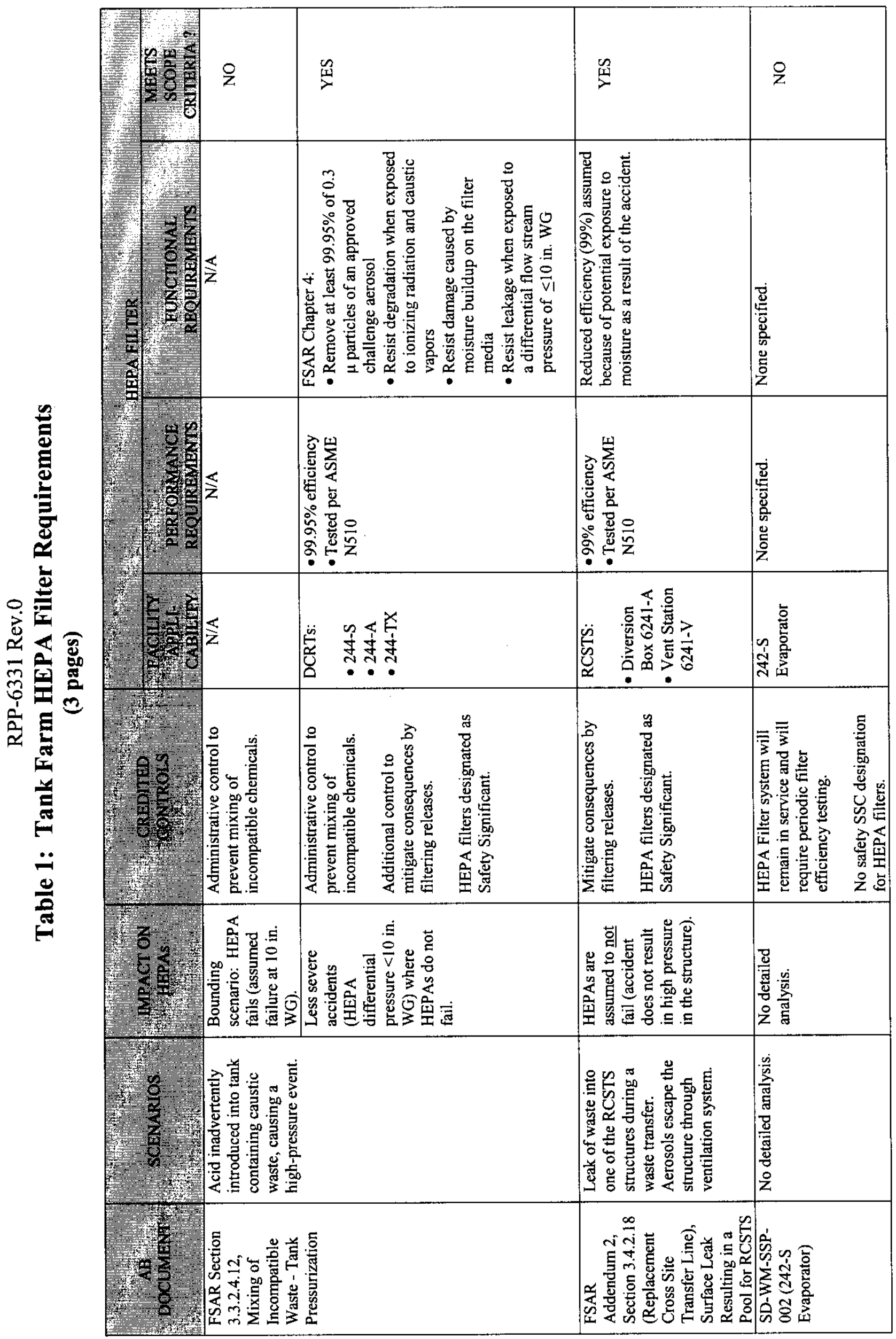




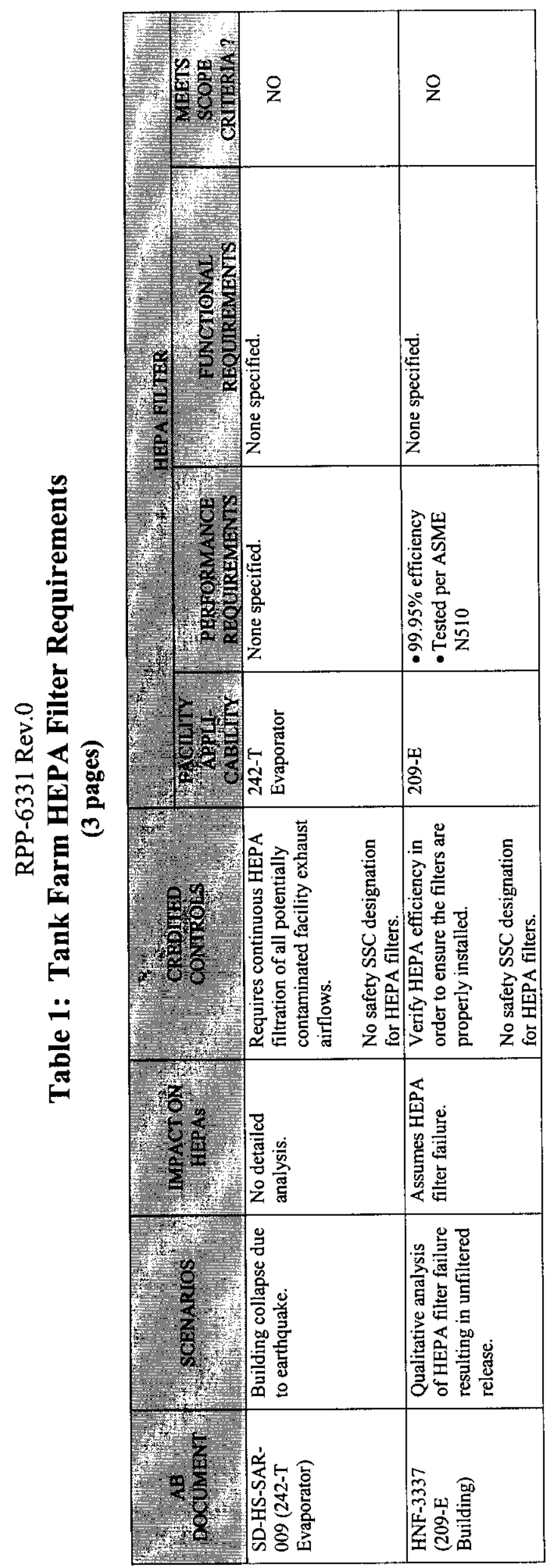

\& 


\title{
RPP-6331 Rev 0
}

Appendix B

Interoffice Memo 74B50-0052

NON-RADIOACTIVE CHEMICAL SOURCE TERM TO BE USED FOR THE DOUBLE-SHELL TANK VAPOR SPACE

\author{
Consisting of 4 pages
}

Including this cover page 
From: Process Control

74B50-00-52

Phone: $\quad 372-2493$ R2-11

Date: $\quad$ May 5, 2000

Subject: $\quad$ NON-RADIOACTIVE CHEMICAL SOURCE TERM TO BE USED FOR THE DOUBLE-SHELL TANK VAPOR SPACE

To:

R. D. Gustavson

R3-83

Copies:

N. W. Kirch

R2-11

THM File/LB

A study was commissioned to determine the vulnerability of high-efficiency particulate air (HEPA) filter due to degradation of the HEPA filter by exposure to chemicals. This letter transmits the HEPA filter chemical exposure source term for ammonia and volatile organics for 244-S, 244-A, and 244-TX Double Contained Receiver Tanks.

Signature copy on file

T. H. May

thm/mjg

Attachment 


\section{HEPA Filter Vulnerability Study Source Term}

HEPA filters for three Double Contained Receiver Tanks (DCRTs) have been exposed to chemicals and may be vulnerable to failure due to damage caused by chemical exposure. This report provides source terms for ammonia and for Volatile Organic Carbon (VOC) compounds. These source terms can be used to determine if the HEPA filters for 244-A, 244-S, and 244-TX are vulnerable.

The basis for the ammonia source term is RPP-4941 Rev. 0A. This document provides an estimate of ammonia concentration inside the receiver tank for each of the DCRTs. The gas inside the receiver tank is purged to the DCRT vault by the air introduced into the tank by a bubbler style liquid level measurement device. The DCRT ventilation then exhausts the vapor in the vault to the atmosphere. Assuming that the tank is at steady state, ammonia concentrations in the exhaust stack are as follows.

\begin{tabular}{|l|c|c|}
\hline \multicolumn{1}{|c|}{ DCRT } & DCRT VENT RATE (CFM) & AMMONIA CONC (mg/m3) \\
\hline $244-\mathrm{A}$ & 150 & 3.9 \\
\hline $244-\mathrm{S}$ & 155 & 21 \\
\hline $244-\mathrm{TX}$ & 125 & 0 \\
\hline
\end{tabular}

The basis for the VOC source term is the TWINS database for Single-Shell Tank (SST) vapor space sampling. It is assumed that every type of feed that has gone through the DCRTs is represented in the SSTs. The source term was generated by selecting the highest concentration of each chemical species found in the headspace of any of the SSTs. The vapor concentration in the SST was adjusted by the ratio of the SST ventilation rate ( $10 \mathrm{cfm}$ for breather filters) divided by the DCRT ventilation rate to account for higher dilution of the vapor space in the DCRT as compared to the SSTs. This conservative concentration can be used for either of the DCRTs listed above. The concentrations for VOC are very low. Since the DCRT is used only intermittently, HEPA degradation is unlikely.

There is anecdotal evidence that the HEPA filters on tank 241-C-103 experienced problems with the glue that attached the HEPA filter paper to the wood frame. Tank 241-C-103 contains high levels or organic and contains a floating organic layer. The HEPA filters are continuously challenged by VOC. This is not the case in the DCRTs. In addition, a periodic gas release event in tank 241-C-103 vents higher concentrations of VOC into the tank headspace.

Acid or caustic vapors may damage HEPA filters. Since all of the waste in the DCRT is $\mathrm{pH} 7$ or greater, it is unlikely that acid vapors are present. The waste does contain caustic, but the tank contents are cool and the waste is not agitated sufficiently to generate significant caustic aerosols. Damage to the HEPA filters by caustic in these DCRTs is not likely. 


\begin{tabular}{|c|c|c|c|c|c|c|c|}
\hline Toxic Air Pollutant & $\begin{array}{c}\text { CAS * } \\
\text { [F1] }\end{array}$ & $\begin{array}{c}\text { Conc in } \\
\text { DCRT } \\
(\mathrm{mg} / \mathrm{m} 3)\end{array}$ & $\begin{array}{c}\text { Maximum } \\
\text { Reported } \\
\text { (mg/m } 3)\end{array}$ & Toxic Air Pollutant & $\begin{array}{c}\text { CAS \# } \\
\text { [F1] }\end{array}$ & $\begin{array}{c}\text { Conc in } \\
\text { DCRT } \\
(\mathrm{mg} / \mathrm{m} 3)\end{array}$ & $\begin{array}{c}\text { Maximum } \\
\text { Reported } \\
\text { (mg/m 3) }\end{array}$ \\
\hline N-Nitrosom orpholine & $59-89-2$ & $3.8 E-03$ & $4.6 \mathrm{E}-02$ & Mesityl oxide & 141-79-7 & $6.5 E-03$ & $7.9 \mathrm{E}-02$ \\
\hline 1,3-Butadiene & $106-99-0$ & $4.4 E-02$ & $5.4 \mathrm{E}-01$ & Acetonitrile & $75-05-8$ & $2.0 \mathrm{E}+00$ & $2.4 \mathrm{E}+01$ \\
\hline Ethylene dibromide (dibromethane) & $106-93-4$ & $7.1 \mathrm{E}-03$ & $8.7 E-02$ & Cyclohexanone & $108-94-1$ & $3.0 \mathrm{E}-02$ & $3.7 E-01$ \\
\hline Polychlorinated Biphenyls (PCBs) & $1336-36-3$ & $2.9 \mathrm{E}-03$ & $3.5 \mathrm{E}-02$ & Methyl chloride & $74-87-3$ & $1.7 \mathrm{E}-02$ & $2.1 \mathrm{E}-01$ \\
\hline Ethylene oxide & $75-21-8$ & $3.9 E-03$ & $4.8 \mathrm{E}-02$ & n-Propyl nitrate & $627-13-4$ & $9.0 \mathrm{E}-02$ & $1.1 E+00$ \\
\hline Vinyl chloride & $75-01-4$ & $2.5 \mathrm{E}-03$ & $3.1 \mathrm{E}-02$ & Toluene & $108-88-3$ & $3.9 \mathrm{E}-01$ & $4.8 \mathrm{E}+00$ \\
\hline Acrylonitrile & $107-13-1$ & $4.6 \mathrm{E}-04$ & $5.6 \mathrm{E}-03$ & 2-Butoxyethanol & $111-76-2$ & $2.4 \mathrm{E}-02$ & $2.9 \mathrm{E}-01$ \\
\hline 1,4-Dioxane & $123-91-1$ & $4.5 \mathrm{E}-03$ & $5.5 E-02$ & $n-B u t y l$ alcohol & $71-36-3$ & $1.5 \mathrm{E}+01$ & $1.8 \mathrm{E}+02$ \\
\hline 1,2-Dichloroethane (ethylene chloride) & $107-06-2$ & $4.3 \mathrm{E}-03$ & $5.3 E-02$ & Isobutyl alcohol & $78-83-1$ & $4.5 \mathrm{E}-03$ & $5.5 \mathrm{E}-02$ \\
\hline Chloroform & $67-66-3$ & $6.7 \bar{E}-03$ & $8.2 \mathrm{E}-02$ & $n$-Valeraldehyde & $110-62-3$ & $6.9 \mathrm{E}-02$ & $8.4 \mathrm{E}-01$ \\
\hline Carbon tetrachloride & $56-23-5$ & 1.8E-01 & $2.2 E+00$ & Methyl isobutyl ketone (MIBK) & $108-10-1$ & $3.1 \mathrm{E}-01$ & $3.8 \mathrm{E}+00$ \\
\hline Benzene & $71-43-2$ & $5.6 \mathrm{E}-01$ & $6.8 \mathrm{E}+00$ & Cyclohexanol & $108-93-0$ & $1.6 \mathrm{E}-04$ & $2.0 \mathrm{E}-03$ \\
\hline Acetaldehyde & $75-07-0$ & $5.2 E-02$ & $6.4 \mathrm{E}-01$ & Ethyl butyl ketone & $106-35-4$ & $2.7 E-01$ & $3.3 E+00$ \\
\hline Dichloromethane (methylene chloride) & $75-09-2$ & $5.7 \mathrm{E}-01$ & $6.9 E+00$ & Methyl isoamyl keton $\theta$ & $110-12-3$ & $1.5 \mathrm{E}-02$ & $1.8 \mathrm{E}-01$ \\
\hline Trichloroethylene & $79-01-6$ & $3.4 \mathrm{E}-02$ & $4.1 \mathrm{E}-01$ & Methyl n-amyl ketone & $110-43-0$ & $2.3 E-01$ & $2.8 \mathrm{E}+00$ \\
\hline Perchloroethylene (tetrachloroethylene) & $127-18-4$ & $5.8 \mathrm{E}-02$ & $7.1 \mathrm{E}-01$ & Diprophyl ketone & 123-19-3 & $1.6 \mathrm{E}-01$ & $2.0 \mathrm{E}+00$ \\
\hline 1,4-Dichlorobenzene & $106-46-7$ & $4.2 E-03$ & $5.1 \mathrm{E}-02$ & a-Methyl styrene & $98-83-9$ & $1.1 \mathrm{E}-03$ & $1.3 E-02$ \\
\hline Bis(2-ethylhexyl)phthalate (DEHP) & $117-81-7$ & $3.8 \mathrm{E}-04$ & $4.6 \mathrm{E}-03$ & Methyl form ate & $107-31-3$ & $1.5 \mathrm{E}-04$ & $1.8 E-03$ \\
\hline N-Nitrosodimethylamine & $62-75-9$ & $2.0 \mathrm{E}-02$ & $2.5 E-01$ & Cumene & $98-82-8$ & $3.5 \mathrm{E}-02$ & 4.3E-01 \\
\hline 1,2-Dichloropropane & 78-87-5 & $5.3 E-03$ & $6.5 \mathrm{E}-02$ & Nitromethane & $75-52-5$ & 1.1E-02 & 1.3E-01 \\
\hline Acrolein & 107-02-8 & 1.1E-03 & $1.4 \mathrm{E}-02$ & Methyl alcohol & $67-56-1$ & $2.4 \mathrm{E}+00$ & $2.9 E+01$ \\
\hline Methyl isocyanato & $624-83-9$ & $3.4 \mathrm{E}-03$ & 4.2E-02 & Ethyl benzene & $100-41-4$ & $5.4 \mathrm{E}-02$ & $6.6 \mathrm{E}-01$ \\
\hline Acrylic acid & $79-10-7$ & $3.3 E-01$ & $4.0 E+00$ & Styrene & $100 \cdot 42-5$ & $9.8 \mathrm{E}-02$ & $1.2 \mathrm{E}+00$ \\
\hline Hexachlorobutadiene & $87-68-3$ & $9.8 \mathrm{E}-03$ & $1.2 \mathrm{E}-01$ & tert-Butyl alcohol & $75-65-0$ & $2.7 E-02$ & $3.3 \mathrm{E}-01$ \\
\hline Allyl chloride & $107-05-1$ & $1.6 \mathrm{E}-03$ & $2.0 \mathrm{E}-02$ & sec-Butyl alcohol & $78-92-2$ & $5.1 \mathrm{E}-02$ & $6.2 \mathrm{E}-01$ \\
\hline Methyl hydrazine & $60-34-4$ & $2.0 \mathrm{E}-04$ & $2.5 \mathrm{E}-03$ & Methyl ethyl ketone (MEK) & $78-93-3$ & $3.1 E+00$ & $3.8 E+01$ \\
\hline Nitrobenzene & $98-95-3$ & 1,1E-03 & $1.4 \mathrm{E}-02$ & o-Dichlorobenzene (1,2-Dichlorob & $95-50-1$ & $4.5 \mathrm{E}-03$ & $5.5 \mathrm{E}-02$ \\
\hline p-Nitrochlorobenzene & $100-00-5$ & $4.0 \mathrm{E}-04$ & $4.9 E-03$ & Isoamyl alcohol & $123-51-3$ & $8.0 \mathrm{E}-03$ & $9.8 \mathrm{E}-02$ \\
\hline Diphenylamine & $122-39-4$ & $1.7 \mathrm{E}-02$ & $2.1 \mathrm{E}-01$ & Xylenes (m-,o-,p-isomers) & $1330-20-7$ & $1.1 \mathrm{E}-01$ & $1.4 \mathrm{E}+00$ \\
\hline 1,1-Dimethylhydrazine & $57-14-7$ & $6.1 \mathrm{E}-04$ & $7.5 E-03$ & n-Propyl alcohol & $71-23-8$ & $3.9 \mathrm{E}-01$ & $4.7 E+00$ \\
\hline Biphenyl & $92-52-4$ & $1.1 E+00$ & $1.4 \mathrm{E}+01$ & Tetrahydrofuran & $109-99-9$ & $1.2 \mathrm{E}+00$ & $1.5 E+01$ \\
\hline Methyl bromide & $74-83-9$ & $4.8 \mathrm{E}-03$ & $5.9 E-02$ & Methyl acetate & $79-20-9$ & $1.1 \mathrm{E}-02$ & $1.3 \mathrm{E}-01$ \\
\hline Tributyl phosphate & $126-73-8$ & $4.8 \mathrm{E}-01$ & $5.9 E+00$ & Methyl propyl ketone & $107-87-9$ & $3.4 \mathrm{E}-01$ & $4.1 E+00$ \\
\hline Methylacrylonitrile & $126-98-7$ & $8.2 E-03$ & $1.0 \mathrm{E}-01$ & Methyl isopropyl ketone & $563-80-4$ & $5.3 \mathrm{E}-01$ & $6.5 \mathrm{E}+00$ \\
\hline Propylene imine & $75-55-8$ & $1,1 \mathrm{E}-02$ & $1.3 E-01$ & Diethyl ketone & $96-22-0$ & $3.2 \mathrm{E}-03$ & $3.9 \mathrm{E}-02$ \\
\hline Allyl alcohol & $107-18-6$ & $7.1 \mathrm{E}-04$ & $8.7 \mathrm{E}-03$ & n-Butyl acetate & $123-86-4$ & $1.3 E+00$ & $1.6 \mathrm{E}+01$ \\
\hline Cyanides, as CN $(\mathrm{mg} / \mathrm{m} 3$ of $\mathrm{CN})$ & $51-12-5$ & $2.3 \mathrm{E}+00$ & $2.8 \mathrm{E}+01$ & 1,1-Dichloroethane & $75-34-3$ & $4.0 \mathrm{E}-03$ & $4.9 \mathrm{E}-02$ \\
\hline Diethyl phthalate & $84-66-2$ & $9.8 E-02$ & $1.2 \mathrm{E}+00$ & Isopropyl alcohol & $67-63-0$ & $3.9 E-01$ & $4.8 \mathrm{E}+00$ \\
\hline Dibutyl phthalate & $84-74-2$ & $4.5 E-04$ & $5.5 E-03$ & Cyclohexane & $110-82-7$ & $3.2 \mathrm{E}-01$ & $3.9 \mathrm{E}+00$ \\
\hline 1,2-Epoxybutane & $106-88-7$ & $2.0 \mathrm{E}-02$ & $2.5 E-01$ & Cyclohexene & $110-83-8$ & $7.5 \mathrm{E}-04$ & $9.2 \mathrm{E}-03$ \\
\hline 1-Nitropropane & $108-03-2$ & $1.1 \mathrm{E}-02$ & $1.3 \mathrm{E}-01$ & Isopropyl ether & $108-20-3$ & $3.3 E-02$ & 4.0E-01 \\
\hline Crotonaldehyde & $4170-30-3$ & $5.4 E-03$ & $6.6 \mathrm{E}-02$ & Nonane & $111-84-2$ & $1.3 E-01$ & $1.6 E+00$ \\
\hline Phenyl ether & $101-84-8$ & $1.4 \mathrm{E}-02$ & $1.7 E-01$ & Octane & $111-65-9$ & $1.3 \mathrm{E}-01$ & $1.6 \mathrm{E}+00$ \\
\hline $1,1,2,2$-Tetrachloroethane & $79-34-5$ & $1.6 \mathrm{E}-02$ & $1.9 \mathrm{E}-01$ & Ethyl acetate & $141-78-6$ & $3.5 \mathrm{E}+00$ & $4.3 E+01$ \\
\hline 2,6 -Ditert, butyl-p-cresol & $128-37-0$ & $3.8 \mathrm{E}-01$ & $4.6 E+00$ & Methylcyclohexane & $108-87-2$ & $1.2 \mathrm{E}-01$ & $1.5 \mathrm{E}+00$ \\
\hline Pyridine & $110-86-1$ & $3.5 \mathrm{E}-02$ & $4.3 E-01$ & Heptane (n-Heptane) & $142-82-5$ & $3.3 \mathrm{E}-01$ & $4,0 E+00$ \\
\hline Formamide & $75-12-7$ & $6.3 E-04$ & $7.7 \mathrm{E}-03$ & Methyl acetylene & $74-99-7$ & $4.6 E-02$ & $5.6 \mathrm{E}-01$ \\
\hline Phenol & $108-95-2$ & $6.6 \mathrm{E}-03$ & $8.0 E-02$ & Cyclopentane & $287-92-3$ & $4.9 \mathrm{E}-02$ & $6.0 \mathrm{E}-01$ \\
\hline 2-Hexanone (MBK) & $591-78-6$ & $2.2 \mathrm{E}-01$ & $2.7 \mathrm{E}+00$ & Acetone & $67-64-1$ & $4.1 E+00$ & $5.0 \mathrm{E}+01$ \\
\hline Vinylidene chloride & $75-35-4$ & $7.5 \mathrm{E}-03$ & $9.1 \mathrm{E}-02$ & Pentane & $109-66-0$ & $8.2 \mathrm{E}-01$ & $1.0 E+01$ \\
\hline Trimethylamine & $75-50-3$ & $1.2 E-01$ & $1.5 \mathrm{E}+00$ & Butane & $106-97-8$ & $1.5 E+00$ & $1.8 \mathrm{E}+01$ \\
\hline Acetic acid & $64-19-7$ & $5.2 \mathrm{E}-02$ & $6.4 \mathrm{E}-01$ & Ethyl alcohol & $64-17-5$ & $3.5 \mathrm{E}+00$ & $4.3 E+01$ \\
\hline Nitric oxide & $10102-43-4$ & $1.8 \mathrm{E}-01$ & $2.2 \mathrm{E}+00$ & Methyl chloroform $(1,1,1-$ Trichlord & $71-55-6$ & $5.2 \mathrm{E}-03$ & $6.3 \mathrm{E}-02$ \\
\hline Carbon disulfide & $75-15-0$ & $2.0 \mathrm{E}-01$ & $2.5 E+00$ & Ethyl chloride & $75-00-3$ & $9.0 \mathrm{E}-03$ & 1.1E-01 \\
\hline Ammonia & $7664-41-7$ & $6.5 E+01$ & $7.9 E+02$ & Chlorodifluoromethane & $75-45-6$ & $4.8 \mathrm{E}-01$ & $5.9 E+00$ \\
\hline Propionic acid & $79-09-4$ & $1.3 \mathrm{E}-03$ & $1.6 \mathrm{E}-02$ & Dichlorodifluoromethane & $75-71-8$ & $9.0 \mathrm{E}-03$ & 1.1E-01 \\
\hline 1,2,4-Trichlorobenzene & $120-82-1$ & $1.1 \mathrm{E}-02$ & $1.3 \mathrm{E}-01$ & Trichlorofluoromethane & 75-69-4 & $1.4 \mathrm{E}+01$ & 1.7E+02 \\
\hline Dimethyl acetamide & 127-19-5 & $3.8 \mathrm{E}-03$ & 4.6E-02 & Dichlorotetrafluoroethane & $76-14-2$ & $1.4 \mathrm{E}-02$ & $1.7 \mathrm{E}-01$ \\
\hline Dichlorofluoromethane & $75-43-4$ & $1.9 \mathrm{E}-02$ & $2.3 E-01$ & 1,1,2-T richloro-1,2,2-trifluorethan & $76-13-1$ & $3.8 E-02$ & $4.6 \mathrm{E}-01$ \\
\hline Chlorobenzene & $108-90-7$ & $6.3 \mathrm{E}-03$ & $7.7 \mathrm{E}-02$ & Propionaldehyde & $123-38-6$ & $4.2 E-02$ & $5.1 \mathrm{E}-01$ \\
\hline Napthalene & $91-20-3$ & $3.7 E-03$ & $4.5 \mathrm{E}-02$ & Acetophenone & $98-86-2$ & $1.8 \mathrm{E}-01$ & $2.2 E+00$ \\
\hline 1,1,2-Trichloroethane & $79-00-5$ & $4.0 \mathrm{E}-02$ & $4.9 \mathrm{E}-01$ & Carbonyl sulfide & $463-58-1$ & $5.2 \mathrm{E}-03$ & $6.4 \mathrm{E}-02$ \\
\hline Vinyl acetate & $108-05-4$ & $2.2 E-04$ & $2.7 \mathrm{E}-03$ & & & & \\
\hline
\end{tabular}


RPP-6331Rev. 0

Appendix C

HEPA Filter Vulnerability Criteria

Consisting of 5 pages

Including this cover page 


\section{HEPA Filter Vulnerability Criteria}

\section{A. Screening Criteria}

The following criteria are used to help determine whether the HEPA filters are potentially vulnerable to degradation factors:

1. Age of filters. If the true age of the filters can not be determined, an estimate will be needed. The estimate may be based upon interviews of facility personnel who recall when the filters were last replaced.

2. Have the filters ever been wetted? This could be due to some type of aerosol or entrained moisture in the air stream coming in contact with the filter media, continual heavy condensation, fire deluge system operation, or other method where the filter could have come in contact with moisture.

3. Has the filter been in a high temperature application, or seen high temperature for a period of time? This would include temperatures $>120^{\circ} \mathrm{C}$.

4. Have the filters been in contact with chemical constituents, which could adversely affect filter components (media, adhesives, frame, etc)? This would include solvents (e.g., acetone), or corrosive chemicals ( hydrofluoric acid, Sodium Chloride), or other reactive chemicals. . In the majority of cases for this to be a concern, it would be necessary for the chemical to condense out of the air stream. However, hydrofluoric acid can affect the filter in the vapor phase. If condensation did not occur, then chemical contact is generally not a concern because the vapor would pass directly through the filter.

5. Have the filters been exposed to high levels of radiation, generally due to filter loading? A conservative threshold of $>5 \times 10^{7} \mathrm{Rad}$ total dose will be used for criteria. For perspective, an accumulated dose of $5 \times 10^{7} \mathrm{rad}$ corresponds to a constant dose rate of approximately $114 \mathrm{rad} / \mathrm{hr}$ for 50 years.

If any of the above screening criteria apply, then use the criteria in Section B to evaluate the potential impacts to the required system performance.

\section{B. Evaluation Criteria}

\section{Aging}

a. If no other factors apply, use the following table (Table 1) for the aging criteria related to adjust the expected filter strength for this evaluation.

b. If more than one question above resulted in a "yes", use the bounding or most conservative criteria identified below for each application.

c. If feasible, perform visual examination of filters installed. This will include examining the filter media to determine if there is any splitting along the crease and if there is sagging.

$>$ If any portion of the gasket material and adhesive is visible, examine to determine if there is deterioration such as crumbling, discoloring, or cracking.

$>$ If the case is plywood, examine to determine if any tape was applied to stop leakage, etc.

Table 1 


\section{RPP-6331Rev. 0}

\begin{tabular}{|l|l|}
\hline \multicolumn{1}{|c|}{ Filter life } & \multicolumn{1}{c|}{ Strength } \\
\hline New & $4.6 \mathrm{psi}$ \\
\hline 5 years in service & $4.1 \mathrm{psi}$ \\
\hline 10 years in service & $3.5 \mathrm{psi}$ \\
\hline 15 years in service & $3 \mathrm{psi}$ \\
\hline 20 years in service & $2.5 \mathrm{psi}$ \\
\hline 25 years in service & $1.9 \mathrm{psi}$ \\
\hline 30 years in service & $1.5 \mathrm{psi}$ \\
\hline
\end{tabular}

\section{Wetting}

a. If question 2 above was answered "yes", use one of the following tables. If the filters have only been wetted and dried once, use Table 2. If the filters have been wetted and dried more than once, use table 3 .

Table 2

Wetted only once

\begin{tabular}{|l|l|}
\hline \multicolumn{1}{|c|}{ Filter life } & \multicolumn{1}{c|}{ Strength } \\
\hline New & $3 \mathrm{psi}$ \\
\hline 5 years in service & $2.7 \mathrm{psi}$ \\
\hline 10 years in service & $2.5 \mathrm{psi}$ \\
\hline 15 years in service & $2.2 \mathrm{psi}$ \\
\hline 20 years in service & $1.9 \mathrm{psi}$ \\
\hline 35 years in service & $1.6 \mathrm{psi}$ \\
\hline 30 years in service & $1.3 \mathrm{psi}$ \\
\hline
\end{tabular}

Table 3

Wetted more than once

\begin{tabular}{|l|l|}
\hline \multicolumn{1}{|c|}{ Filter life } & \multicolumn{1}{c|}{ Strength } \\
\hline New & $0.7 \mathrm{psi}$ \\
\hline 5 years in service & $0.7 \mathrm{psi}$ \\
\hline 10 years in service & $0.7 \mathrm{psi}$ \\
\hline 15 years in service & $0.7 \mathrm{psi}$ \\
\hline 20 years in service & $0.7 \mathrm{psi}$ \\
\hline 35 years in service & $0.7 \mathrm{psi}$ \\
\hline 30 years in service & $0.7 \mathrm{psi}$ \\
\hline
\end{tabular}

b. If feasible, perform a visual examination of the filter to identify discoloration or other signs of wetting to the media or case material.

\section{Temperature}

If the answer to question 4 above was "yes", use one of the following tables. If the filter was exposed to a temperature greater than $120^{\circ} \mathrm{C}$ but less than $250^{\circ} \mathrm{C}$ use, Table 4 . If the filter was exposed to a temperature $>250^{\circ} \mathrm{C}$, use Table 5 . 
Table 4

Temperature Range $120^{\circ}-250^{\circ} \mathrm{C}$

\begin{tabular}{|c|c|c|c|}
\hline $\begin{array}{l}\text { Exposure } \\
\text { Time }\end{array}$ & $\begin{array}{l}\text { Non- } \\
\text { Wetted } \\
\text { Strength }\end{array}$ & $\begin{array}{l}\text { Wetted } \\
\text { Strength } \\
\text { (once) }\end{array}$ & $\begin{array}{l}\text { Wetted } \\
\text { Strength } \\
\text { (> once) }\end{array}$ \\
\hline \multicolumn{4}{|l|}{ New filter } \\
\hline $1 \mathrm{hr}$ & $3.87 \mathrm{psi}$ & $2.7 \mathrm{psi}$ & $0.63 \mathrm{psi}$ \\
\hline $10 \mathrm{hrs}$ & $3.23 \mathrm{psi}$ & $2.25 \mathrm{psi}$ & $0.63 \mathrm{psi}$ \\
\hline $100 \mathrm{hrs}$ & $3.01 \mathrm{psi}$ & $2.1 \mathrm{psi}$ & $0.63 \mathrm{psi}$ \\
\hline $1000 \mathrm{hrs}$ & $3.01 \mathrm{psi}$ & $2.1 \mathrm{psi}$ & $0.63 \mathrm{psi}$ \\
\hline \multicolumn{4}{|l|}{5 years } \\
\hline $1 \mathrm{hr}$ & $3.51 \mathrm{psi}$ & $2.43 \mathrm{psi}$ & $0.63 \mathrm{psi}$ \\
\hline $10 \mathrm{hrs}$ & $2.93 \mathrm{psi}$ & $2.03 \mathrm{psi}$ & $0.63 \mathrm{psi}$ \\
\hline 100 hrs & $2.73 \mathrm{psi}$ & $1.89 \mathrm{psi}$ & $0.63 \mathrm{psi}$ \\
\hline $1000 \mathrm{hrs}$ & $2.73 \mathrm{psi}$ & $1.89 \mathrm{psi}$ & $0.63 \mathrm{psi}$ \\
\hline \multicolumn{4}{|l|}{10 years } \\
\hline $1 \mathrm{hr}$ & $3.24 \mathrm{psi}$ & $2.25 \mathrm{psi}$ & $0.63 \mathrm{psi}$ \\
\hline $10 \mathrm{hrs}$ & $2.7 \mathrm{psi}$ & $1.88 \mathrm{psi}$ & $0.63 \mathrm{psi}$ \\
\hline $100 \mathrm{hrs}$ & $2.52 \mathrm{psi}$ & $1.75 \mathrm{psi}$ & 0.63 psi \\
\hline $1000 \mathrm{hrs}$ & $2.52 \mathrm{psi}$ & $1.75 \mathrm{psi}$ & $0.63 \mathrm{psi}$ \\
\hline \multicolumn{4}{|l|}{15 years } \\
\hline $1 \mathrm{hr}$ & $2.88 \mathrm{psi}$ & $1.98 \mathrm{psi}$ & $0.63 \mathrm{psi}$ \\
\hline $10 \mathrm{hrs}$ & $2.4 \mathrm{psi}$ & $1.65 \mathrm{psi}$ & $0.63 \mathrm{psi}$ \\
\hline $100 \mathrm{hrs}$ & $2.24 \mathrm{psi}$ & $1.54 \mathrm{psi}$ & $0.63 \mathrm{psi}$ \\
\hline $1000 \mathrm{hrs}$ & $2.24 \mathrm{psi}$ & $1.54 \mathrm{psi}$ & $0.63 \mathrm{psi}$ \\
\hline \multicolumn{4}{|l|}{20 years } \\
\hline $1 \mathrm{hr}$ & $2.52 \mathrm{psi}$ & $1.71 \mathrm{psi}$ & $0.63 \mathrm{psi}$ \\
\hline $10 \mathrm{hrs}$ & $2.1 \mathrm{psi}$ & $1.43 \mathrm{psi}$ & $0.63 \mathrm{psi}$ \\
\hline $100 \mathrm{hrs}$ & $1.96 \mathrm{psi}$ & $1.33 \mathrm{psi}$ & $0.63 \mathrm{psi}$ \\
\hline $1000 \mathrm{hrs}$ & $1.96 \mathrm{psi}$ & $1.33 \mathrm{psi}$ & $0.63 \mathrm{psi}$ \\
\hline \multicolumn{4}{|l|}{25 years } \\
\hline $1 \mathrm{hr}$ & $2.16 \mathrm{psi}$ & $1.44 \mathrm{psi}$ & $0.63 \mathrm{psi}$ \\
\hline $10 \mathrm{hrs}$ & $1.8 \mathrm{psi}$ & $1.2 \mathrm{psi}$ & $0.63 \mathrm{psi}$ \\
\hline $100 \mathrm{hrs}$ & $1.68 \mathrm{psi}$ & $1.12 \mathrm{psi}$ & $0.63 \mathrm{psi}$ \\
\hline $1000 \mathrm{hrs}$ & $1.68 \mathrm{psi}$ & $1.12 \mathrm{psi}$ & $0.63 \mathrm{psi}$ \\
\hline \multicolumn{4}{|l|}{30 years } \\
\hline $1 \mathrm{hr}$ & $1.8 \mathrm{psi}$ & $1.17 \mathrm{psi}$ & $0.63 \mathrm{psi}$ \\
\hline $10 \mathrm{hrs}$ & $1.5 \mathrm{psi}$ & $0.98 \mathrm{psi}$ & $0.63 \mathrm{psi}$ \\
\hline $100 \mathrm{hrs}$ & $1.4 \mathrm{psi}$ & $0.91 \mathrm{psi}$ & $0.63 \mathrm{psi}$ \\
\hline $1000 \mathrm{hrs}$ & $1.4 \mathrm{psi}$ & $0.91 \mathrm{psi}$ & $0.63 \mathrm{psi}$ \\
\hline
\end{tabular}

\begin{tabular}{|c|c|c|c|}
\hline $\begin{array}{l}\text { Exposure } \\
\text { Time }\end{array}$ & $\begin{array}{l}\text { Non- } \\
\text { Wetted } \\
\text { Strength }\end{array}$ & $\begin{array}{l}\text { Wetted } \\
\text { Strength } \\
\text { (once) }\end{array}$ & $\begin{array}{l}\text { Wetted } \\
\text { Strength } \\
\text { (> once) }\end{array}$ \\
\hline \multicolumn{4}{|l|}{ New filter } \\
\hline $1 \mathrm{hr}$ & $3.44 \mathrm{psi}$ & $2.4 \mathrm{psi}$ & $0.56 \mathrm{psi}$ \\
\hline $10 \mathrm{hrs}$ & $2.58 \mathrm{psi}$ & $1.8 \mathrm{psi}$ & $0.56 \mathrm{psi}$ \\
\hline $100 \mathrm{hrs}$ & $2.15 \mathrm{psi}$ & $1.5 \mathrm{psi}$ & $0.56 \mathrm{psi}$ \\
\hline $1000 \mathrm{hrs}$ & $2.15 \mathrm{psi}$ & $1.5 \mathrm{psi}$ & $0.56 \mathrm{psi}$ \\
\hline \multicolumn{4}{|l|}{5 years } \\
\hline $1 \mathrm{hr}$ & $3.12 \mathrm{psi}$ & $2.16 \mathrm{psi}$ & $0.56 \mathrm{psi}$ \\
\hline $10 \mathrm{hrs}$ & $2.34 \mathrm{psi}$ & $1.62 \mathrm{psi}$ & $0.56 \mathrm{psi}$ \\
\hline $100 \mathrm{hrs}$ & $1.95 \mathrm{psi}$ & $1.35 \mathrm{psi}$ & $0.56 \mathrm{psi}$ \\
\hline 1000 hrs & $1.95 \mathrm{psi}$ & $1.35 \mathrm{psi}$ & $0.56 \mathrm{psi}$ \\
\hline \multicolumn{4}{|l|}{10 years } \\
\hline $1 \mathrm{hr}$ & $2.88 \mathrm{psi}$ & $2 \mathrm{psi}$ & $0.56 \mathrm{psi}$ \\
\hline $10 \mathrm{hrs}$ & $2.16 \mathrm{psi}$ & $1.5 \mathrm{psi}$ & $0.56 \mathrm{psi}$ \\
\hline $100 \mathrm{hrs}$ & $1.8 \mathrm{psi}$ & $1.25 \mathrm{psi}$ & $0.56 \mathrm{psi}$ \\
\hline 1000 hrs & $1.8 \mathrm{psi}$ & $1.25 \mathrm{psi}$ & $0.56 \mathrm{psi}$ \\
\hline \multicolumn{4}{|l|}{15 years } \\
\hline $1 \mathrm{hr}$ & $2.56 \mathrm{psi}$ & $1.76 \mathrm{psi}$ & $0.56 \mathrm{psi}$ \\
\hline $10 \mathrm{hrs}$ & $1.92 \mathrm{psi}$ & $1.32 \mathrm{psi}$ & $0.56 \mathrm{psi}$ \\
\hline $100 \mathrm{hrs}$ & $1.6 \mathrm{psi}$ & $1.1 \mathrm{psi}$ & $0.56 \mathrm{psi}$ \\
\hline $1000 \mathrm{hrs}$ & $1.6 \mathrm{psi}$ & $1.1 \mathrm{psi}$ & $0.56 \mathrm{psi}$ \\
\hline \multicolumn{4}{|l|}{20 years } \\
\hline $1 \mathrm{hr}$ & $2.24 \mathrm{psi}$ & $1.52 \mathrm{psi}$ & $0.56 \mathrm{psi}$ \\
\hline $10 \mathrm{hrs}$ & $1.68 \mathrm{psi}$ & $1.14 \mathrm{psi}$ & $0.56 \mathrm{psi}$ \\
\hline $100 \mathrm{hrs}$ & $1.4 \mathrm{psi}$ & $.095 \mathrm{psi}$ & $0.56 \mathrm{psi}$ \\
\hline $1000 \mathrm{hrs}$ & $1.4 \mathrm{psi}$ & $.095 \mathrm{psi}$ & $0.56 \mathrm{psi}$ \\
\hline \multicolumn{4}{|l|}{25 years } \\
\hline $1 \mathrm{hr}$ & $1.92 \mathrm{psi}$ & $1.28 \mathrm{psi}$ & $0.56 \mathrm{psi}$ \\
\hline $10 \mathrm{hrs}$ & $1.44 \mathrm{psi}$ & $0.96 \mathrm{psi}$ & $0.56 \mathrm{psi}$ \\
\hline $100 \mathrm{hrs}$ & $1.2 \mathrm{psi}$ & $0.8 \mathrm{psi}$ & $0.56 \mathrm{psi}$ \\
\hline $1000 \mathrm{hrs}$ & $1.2 \mathrm{psi}$ & $0.8 \mathrm{psi}$ & $0.56 \mathrm{psi}$ \\
\hline \multicolumn{4}{|l|}{30 years } \\
\hline $1 \mathrm{hr}$ & $1.6 \mathrm{psi}$ & $1.04 \mathrm{psi}$ & $0.56 \mathrm{psi}$ \\
\hline $10 \mathrm{hrs}$ & $1.2 \mathrm{psi}$ & $0.78 \mathrm{psi}$ & $0.56 \mathrm{psi}$ \\
\hline $100 \mathrm{hrs}$ & $1 \mathrm{psi}$ & $0.65 \mathrm{psi}$ & $0.56 \mathrm{psi}$ \\
\hline $1000 \mathrm{hrs}$ & $1 \mathrm{psi}$ & $0.65 \mathrm{psi}$ & $0.56 \mathrm{psi}$ \\
\hline
\end{tabular}

Table 5

Temperature Range $>250^{\circ} \mathrm{C}$ 


\section{Chemicals}

There is no data to show the correlation between filter strength or efficiency and chemicals. As a result, this will be left up to the facilities to provide information whether or not vulnerability exists. One indication could be the visual examination used for wetting identified in Section 2 above.

\section{Radiation Exposure}

A conservative threshold of $>5 \times 10^{7} \mathrm{Rad}$ total dose will used for criteria. This equates to $114 \mathrm{Rad} / \mathrm{hr}$ for 50 years. Since there is no data available relating to the degradation and the reduction in strength, if the filters have been exposed to $>5 \times 10^{7} \mathrm{Rad}$ total dose, these filters need to be identified as vulnerable. 